\title{
Root responses to domestication,
} precipitation and silicification: weeping meadow grass simplifies and alters toughness

Article

Accepted Version

Ryalls, J. M. W., Moore, B. D., Johnson, S. N., Connor, M. and Hiltpold, I. (2018) Root responses to domestication, precipitation and silicification: weeping meadow grass simplifies and alters toughness. Plant and Soil, 427 (1-2). pp. 291-304. ISSN 0032-079X doi: https://doi.org/10.1007/s11104018-3650-5 Available at https://centaur.reading.ac.uk/77326/

It is advisable to refer to the publisher's version if you intend to cite from the work. See Guidance on citing.

To link to this article DOI: http://dx.doi.org/10.1007/s11104-018-3650-5

Publisher: Springer

All outputs in CentAUR are protected by Intellectual Property Rights law, including copyright law. Copyright and IPR is retained by the creators or other copyright holders. Terms and conditions for use of this material are defined in the End User Agreement. 


\section{CentAUR}

Central Archive at the University of Reading

Reading's research outputs online 
Root responses to domestication, precipitation and silicification: weeping meadow grass simplifies and alters toughness

James M.W. Ryalls ${ }^{1,2 *}$, Ben D. Moore ${ }^{1}$, Scott N. Johnson ${ }^{1}$, Myles Connor ${ }^{1}$ and Ivan Hiltpold ${ }^{1,3}$

${ }^{1}$ Hawkesbury Institute for the Environment, Western Sydney University, Richmond, NSW, Australia

${ }^{2}$ Current address: Centre for Agri-Environmental Research, School of Agriculture, Policy and Development,

University of Reading, UK

${ }^{3}$ Current address: Department of Entomology and Wildlife Ecology, University of Delaware, USA

*Corresponding author: $\quad$ J.Ryalls@westernsydney.edu.au

Tel: +61245701088

Running title: Grass domestication impacts root traits 
Keywords: deluge, drought, fracture strain, root architectural complexity, root trait selection, tensile strength

\section{Abstract}

Background and Aims

Plant breeding usually focuses on conspicuous above-ground plant traits, yet roots fundamentally underpin plant fitness. Roots show phenotypic plasticity in response to soil

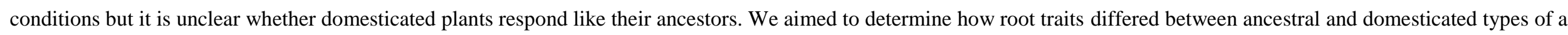
meadow grass (Microlaena stipoides) under altered regimes of precipitation and soil silicon availability.

\section{Methods}

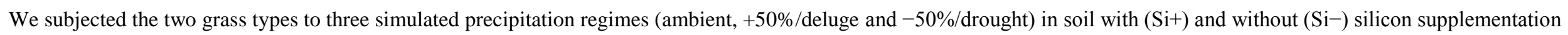
and then characterised root biomass, architectural complexity and toughness in addition to shoot traits.

\section{Results}

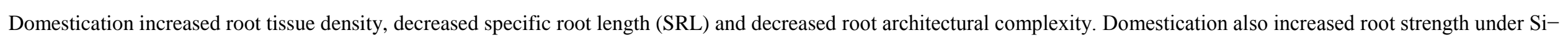
conditions but not $\mathrm{Si}+$ conditions. Fine roots, SRL, architectural complexity and the force required to tear the roots all decreased under deluge. The ancestral and domesticated grasses responded similarly to precipitation, except that the latter had weaker roots (decreased fracture strain) under drought.

\section{Conclusions}

Domestication and increased precipitation caused changes in $M$. stipoides root traits that could be beneficial against some stresses (e.g. soil compaction, herbivory) but not others (e.g. drought).
Abbreviations
RTD - root tissue density
SRL - specific root length
SRA - specific root area 
ANC - ancestral

DOM - domesticated

$\mathrm{Si}$ - silicon

$\mathrm{N}$ - nitrogen

C-carbon 


\section{Introduction}

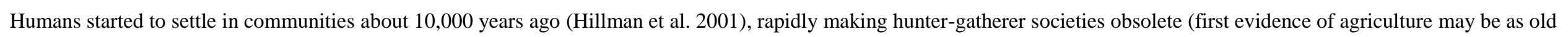

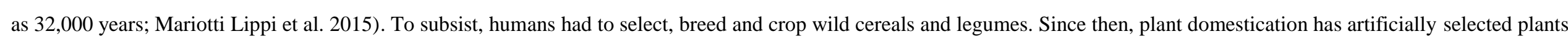

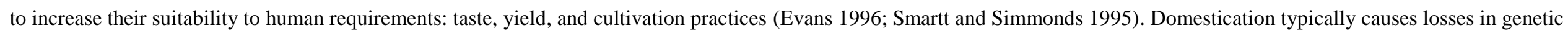
diversity through genetic drift and bottlenecks (Chen et al. 2015 and references therein) and has led to a suite of striking phenotypic changes, collectively referred to as the

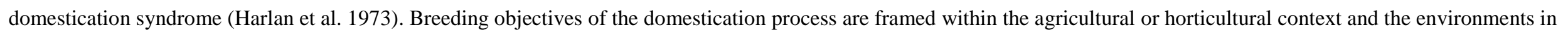

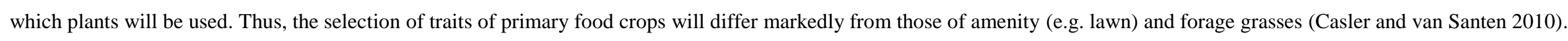
The domestication of turf grasses, in particular, has generally targeted shoot traits such as colour, fine texture, seed quality and tiller density (Huyghe and Brummer 2013).

With the exception of a few species that have been domesticated for their edible roots, root traits are rarely the target of breeding programmes and have been neglected in domestication studies (Marshall et al. 2016). Given that more than $50 \%$ of net primary production is commonly allocated below-ground, sometimes approaching $90 \%$ (Coleman

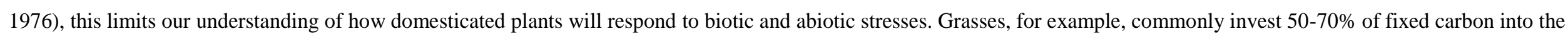

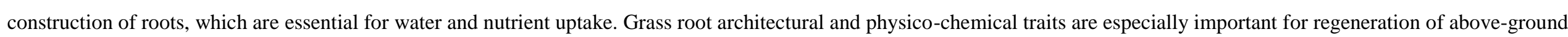
parts after fire or herbivory (i.e. tolerance) and resistance against root herbivore attack, as well as for protection against soil compaction (i.e. the ability to maintain growth in compacted soils) and inadvertent uprooting by grazing ungulates (Gregory 2006; Moore and Johnson 2016).

Water availability can contribute significantly to changes in root architecture. Root traits associated with maintaining plant productivity under drought conditions, for example,

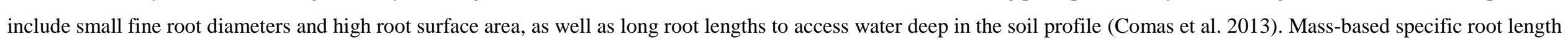

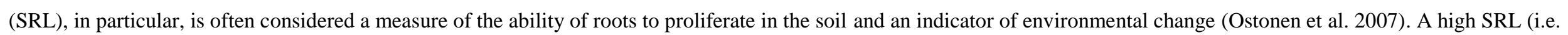

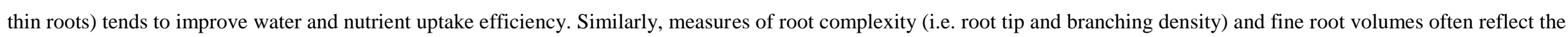
absorptive potential of the root system (Børja et al. 2008).

Silicon (Si), an important element in plant nutrition, can mitigate various biotic and abiotic stresses, including herbivory and drought (Hartley and DeGabriel 2016; Ryalls et al.

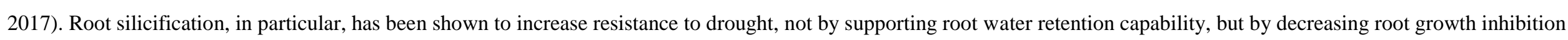

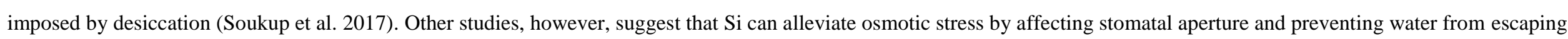

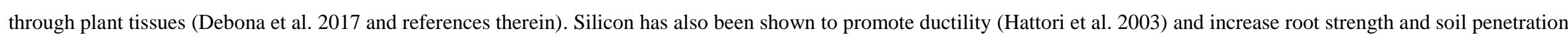

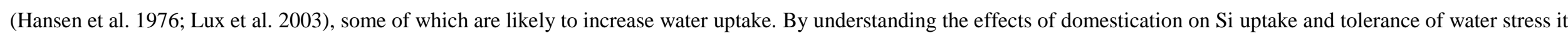


may be possible to tailor future breeding practices that select for positive plant defence traits without sacrificing others (Simpson et al. 2017). One of the most important

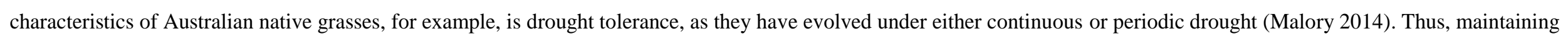
drought-tolerant traits throughout the domestication process are of paramount importance, especially as the variability of rainfall increases (Fita et al. 2015).

Primary plant domestication has frequently selected for a simplification of plant architecture above-ground, with reduced branching and tillering (Chen et al. 2015 and references therein), as these changes in morphology result in higher yields. The greater tillering ability of their ancestors is often related to defence traits to tolerate herbivory, giving plants

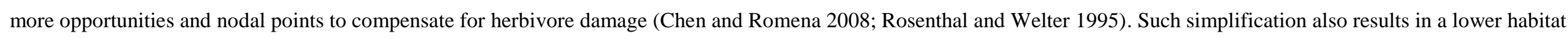

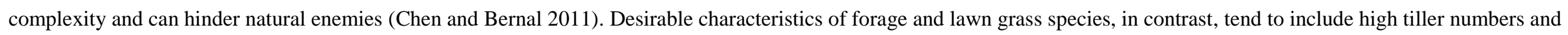

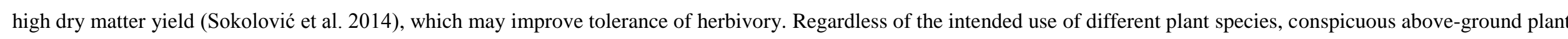

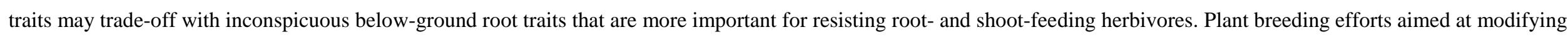

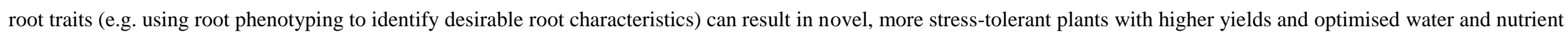
acquisition, yet the responses of root morphology and defence traits to domestication remain largely unknown (Paez-Garcia et al. 2015).

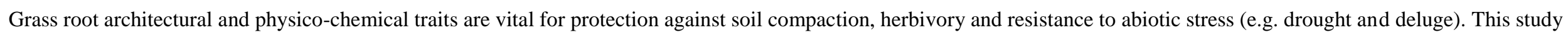

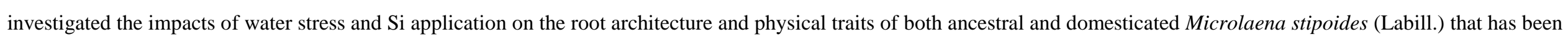
bred over the course of 10 years. We specifically aimed to understand how changes in root morphology can be used to improve plant performance and resist various biotic and

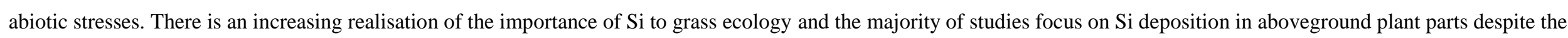

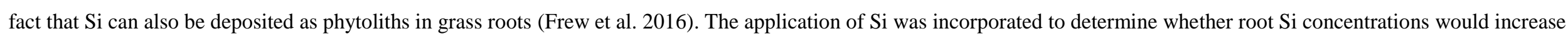
plant stress tolerance. Domestication is an example of rapid evolution by artificial selection and breeding, making it especially suitable for studying trait development on a

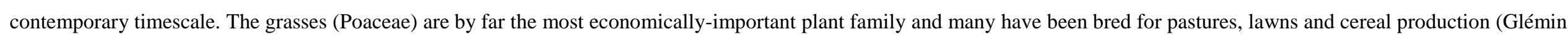
and Bataillon 2009). Microlaena stipoides, in particular, is among the most important native Australian species valued for its high pasture quality for livestock, beneficial architectural traits, large grain size and adaptability to a range of soil types and environments (Mitchell et al. 2014). It has been identified as having potential for commercial

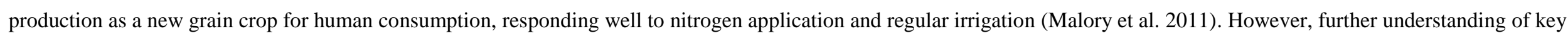
domestication traits of M. stipoides is required to aid the domestication process (Shapter et al. 2013). Beneficial root traits, in particular, that improve plant growth and increase tolerance to herbivory would be important to maintain. Ancestral plants may well express traits that should be reincorporated into domesticated plants. We hypothesised that the

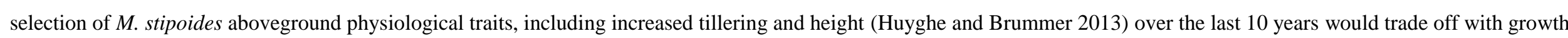

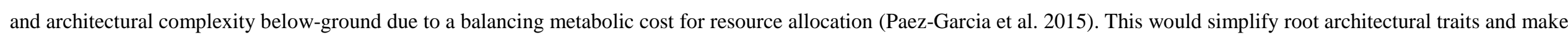


them more susceptible to soil compaction and uprooting by grazing ungulates. In other words, domestication was expected to shift resource allocation in favour of aboveground physiological traits, similar to that found in wheat (Qin et al. 2012). We expected breeding to favour drought-tolerant traits (e.g. increased root length and fine root volume to increase access and uptake of soil water), which would benefit further from increased Si uptake in Si-supplemented plants.

\section{Materials and methods}

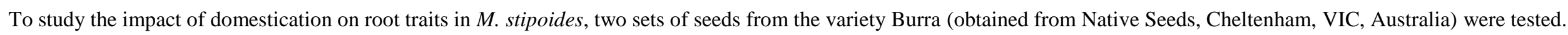

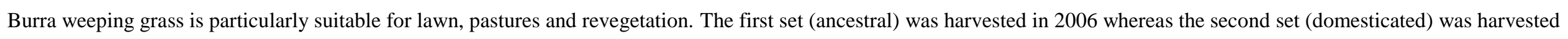
in 2015. Over 10 years, the domesticated type has been subject to selection for colour, persistence and seed production (full details in Mitchell (2013) and references therein).

\section{Plant growth conditions}

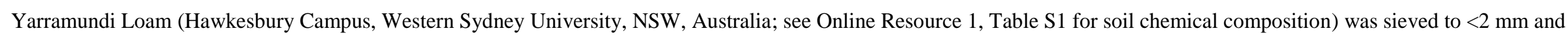

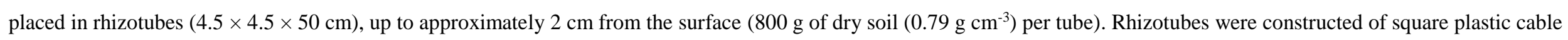

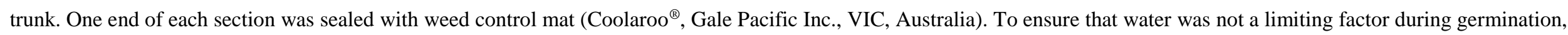

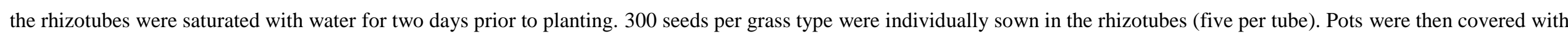

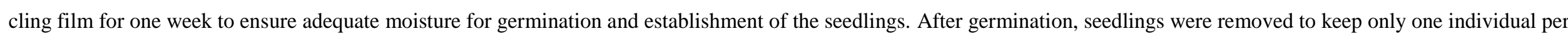
rhizotube.

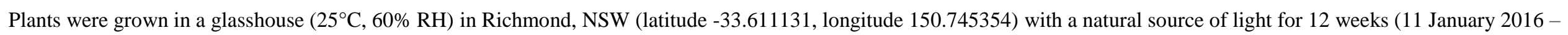

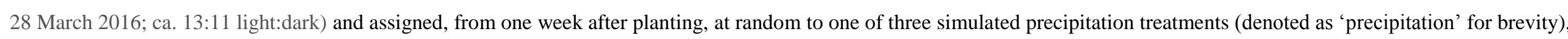

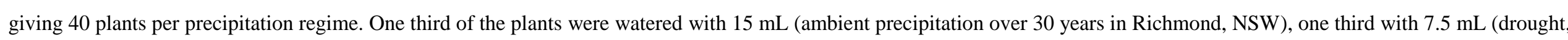

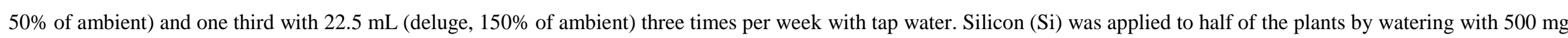

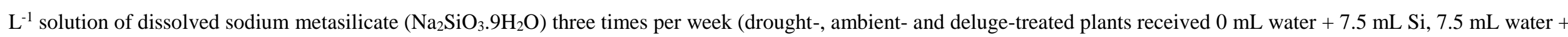

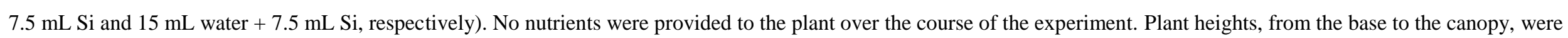
measured weekly from four weeks after sowing until harvest. At week 12, the numbers of grass tillers were counted, the rhizotubes were disassembled and the soil was gently removed from the root systems. The roots were then washed from the remaining soil over $200 \mu \mathrm{m}$ and $20 \mu \mathrm{m}$ stacked sieves.

Root architectural properties 


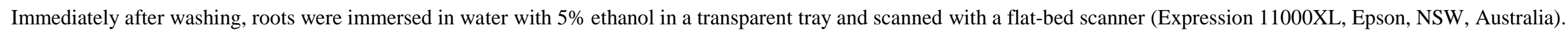

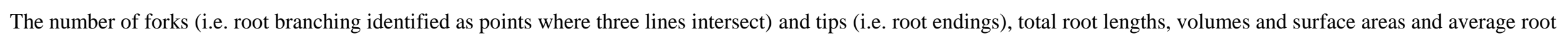

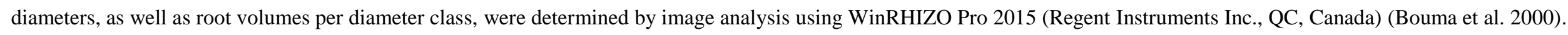
Roots were oven dried at $40{ }^{\circ} \mathrm{C}$ for three days and weighed. Total root dry mass and architectural traits were used to calculate specific root length (SRL; cm $\mathrm{g}^{-1}$ root dry mass),

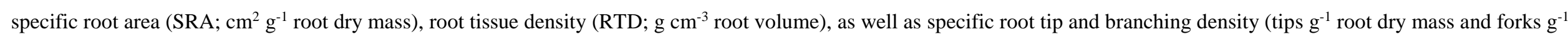
root dry mass, respectively).

\section{Root physical traits}

Two physical traits of the roots of the ancestral and domesticated grasses were measured immediately after scanning (before drying). First the physical strength of the root was

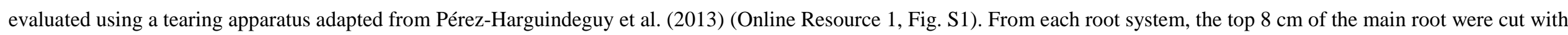
a razor blade and individually scanned and analyzed in WinRHIZO Pro 2015. The average diameter of the root was recorded. Both ends of the section of root were wrapped in

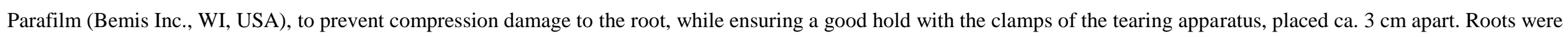
torn apart. The force to fracture the root was recorded using a digital force gauge (FPG-5, Test-Equip, VIC, Australia). Tearing force $\left(F_{\mathrm{t}}\right)$ was calculated as

$$
F_{t}=\frac{\text { Force to fracture }}{\text { Diameter of the tested root }}
$$

and expressed in $\mathrm{N} \mathrm{mm}^{-1}$.

In addition to the tearing force (otherwise referred to as tensile strength), the exact distance between the root tearer clamps was measured prior ( $D_{\mathrm{p}}$, when the root was just under tension) and immediately after $\left(D_{\mathrm{a}}\right)$ the fracture of the root. Root fracture strain, otherwise known as root elongation at break ( $\left.\mathrm{E}_{\mathrm{r}}\right)$, a measure of ductility, was calculated as

$$
E_{r}=\frac{D a-D p}{\text { Diameter of the tested root }}
$$

and expressed in $\mathrm{mm} \mathrm{mm}^{-1}$.

Root chemistry

Dried roots were ball-milled to a fine powder. Carbon and nitrogen concentrations were determined with a Carlo Erba CE1110 elemental analyser and Si concentrations were

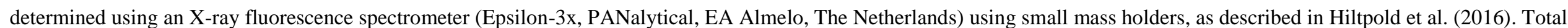


phenolic concentrations in the roots were determined as described in Salminen and Karonen (2011), using a Folin-Ciocalteu assay with gallic acid monohydrate (Sigma-Aldrich, St. Louis, MO, USA) as the quantification standard.

\section{Statistical analyses}

The R statistical interface v3.3.3 (R Core Team 2017) was used for all statistical analyses. The effects of domestication, Si application and precipitation on plant growth (height, root biomass and number of tillers), root strength $\left(\mathrm{F}_{\mathrm{t}}\right.$ and $\mathrm{E}_{\mathrm{r}}$ ), root architecture (total length, surface area and volume, average diameter, RTD, SRA, SRL, root tip and branching density) and root chemistry ( $\mathrm{CN}$ ratio, Si concentrations and total phenolic concentrations) were analysed using general linear models (ANOVA). Plant heights were analysed using a linear mixed model in the nlme statistical package (Pinheiro et al. 2017), with pot number and time (week number) as random effects to account for repeated measures. The fixed terms for all models included grass type (domesticated and ancestral), precipitation regime (drought, ambient and deluge) and $\mathrm{Si}$ application (Si- and $\mathrm{Si}+$ ) as well as the two-way and threeway interactions between these terms. Post-hoc Tukey's tests using the glht function in the package multcomp (Hothorn et al. 2008) were used for pairwise comparisons of means for treatment and interaction effects. Where appropriate, dependent variables were transformed before analysis (Table 1). Correlations between phenolic concentrations, $\mathrm{Si}$ concentrations and root strength and architectural characteristics were determined using the function cor.test in the package stats (R Core Team 2017). Permutational analysis of variance (PERMANOVA) was used to model the multivariate relationship between total raw architectural traits and root mass using the package vegan (Oksanen et al. 2017). A principal component analysis (PCA) was performed to visualise significant treatment effects using the packages stats and ggplot2 (Wickham 2009).

\section{Results}

Plant growth

Plant height significantly increased as simulated precipitation levels increased from drought to deluge, which became clear within eight weeks after sowing (Fig. 1). Domesticated plants grew significantly taller than ancestral plants overall (Table 1). Grass type and precipitation had significant effects on other plant growth characteristics. In particular, domestication increased tiller numbers and root biomass. These characteristics also increased as precipitation increased (Table 1). Si application had no significant effects on plant growth. Full model statistics, including two-way and three-way interaction effects between grass type, precipitation and Si-application, are shown in Table S2 (Online Resource 1).

Root architectural properties

Root biomass was significantly correlated with total root architectural traits (i.e. total volume, surface area and length) overall (PERMANOVA $F_{1,75}=36.458, \mathrm{R}^{2}=0.327, P<$ 0.001). Accounting for changes in root biomass, domestication increased RTD but decreased SRL and SRA. Domestication had no significant effect on average root diameter. Precipitation significantly affected all architectural traits, whereby deluge increased average root diameter and RTD but decreased SRL and SRA compared with ambient precipitation (Table 1). The PCA output combining all architectural traits showed significant overlap between rainfall treatments (Online Resource 1, Fig. S2) and between ancestral 


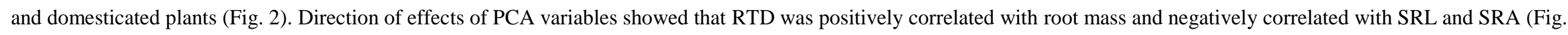

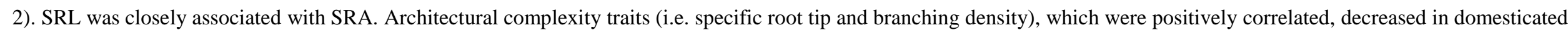

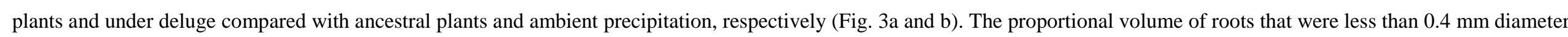
generally decreased with domestication and deluge (Fig. 3c and d, respectively; also see Table 1 and Online Resource 1, Table S2 for full statistics), showing similar patterns to changes in SRL (Fig. 3a and b) and root architectural complexity. Si application had no significant effects on root architectural properties (Online Resource 1, Table S2).

\section{Root physical traits}

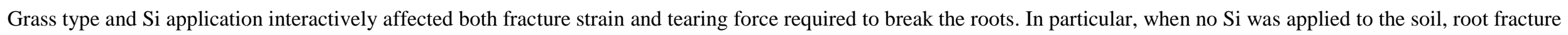
strain and tearing force was greater in domesticated compared with ancestral M. stipoides (Fig. 4a and c, respectively), whereas both physical traits showed opposite, albeit insignificant, responses to domestication when Si was applied to the soil. Grass type and precipitation had a significant interactive effect on fracture strain, whereby ancestral $M$.

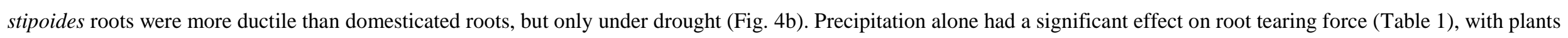
under deluge requiring significantly less force to break the roots than those under drought and ambient conditions (Fig. 4d).

\section{Root chemistry}

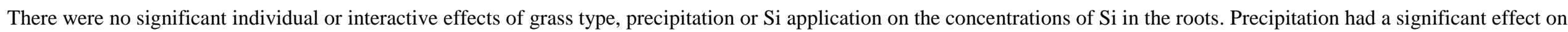
root $\mathrm{C}: \mathrm{N}$, with lower $\mathrm{C}$ and higher $\mathrm{N}$ in roots of plants that were subjected to deluge compared with those subjected to drought and ambient precipitation treatments. Total root phenolics were significantly affected by the interaction between grass type and precipitation, whereby concentrations in ancestral plants were significantly higher than those in

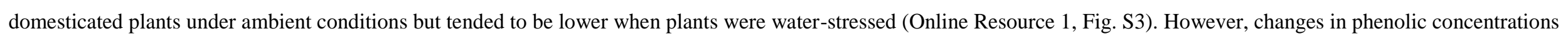

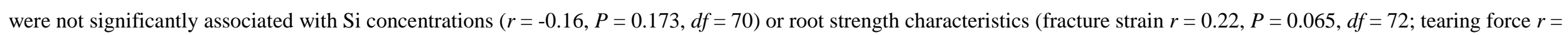
$0.06, P=0.612, d f=72)$.

\section{Discussion}

Domestication of an Australian native grass

Domestication of Microlaena stipoides clearly has an impact on plant growth and root architecture, affecting eight of the nine characteristics measured. After ca. 10 years of selection, domesticated M. stipoides grew taller and had more tillers compared with plants grown from ancestral germplasm, as expected. Higher tillering and growth were likely

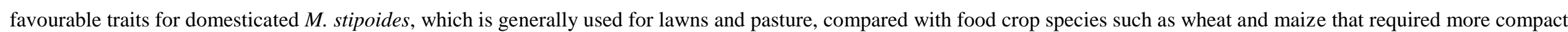




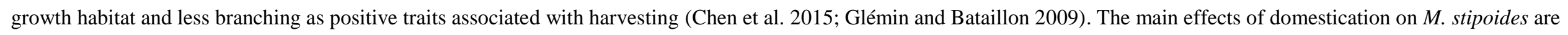
visualised in Fig. 5, with numbers referring to relevant figures associated with each effect.

Domestication had clear impacts on root architecture overall, although domesticated plants showed surprisingly less homogeneity in architecture (i.e. PCA clustering) than we

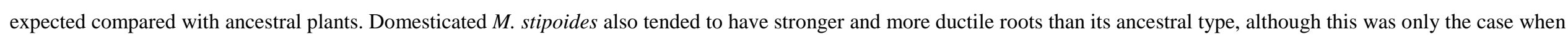

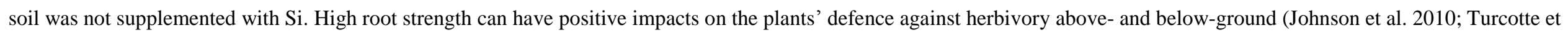

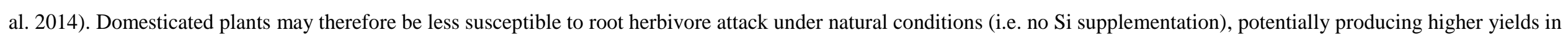

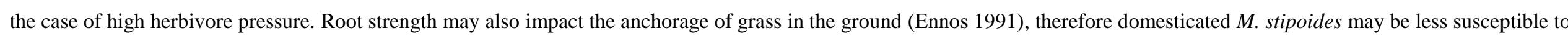
uprooting by mammalian grazing above-ground. Selecting $M$. stipoides as a pasture species may have favoured a stronger and more ductile root system to increase resilience to

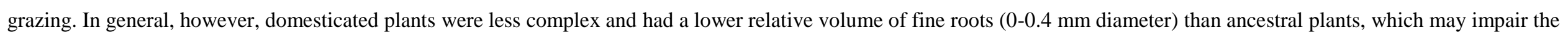
ability of M. stipoides to tolerate disturbance (e.g. uprooting and tearing of tillers). The extent to which a simpler root system will affect abiotic and/or biotic resistance and

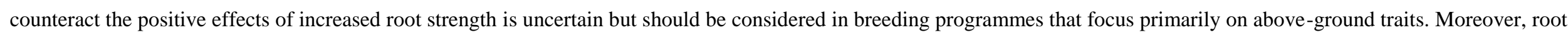

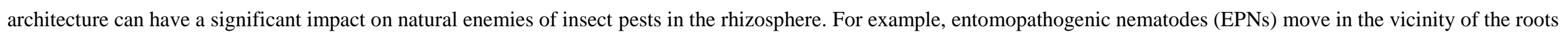

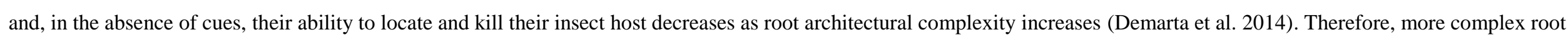
systems could negatively impact higher trophic levels in the event of root herbivory.

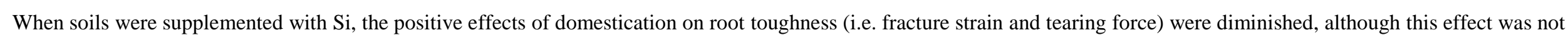
associated with an increase in root Si concentrations. In particular, there were no clear effects of Si application on root Si concentrations, although any stored silicon, which is

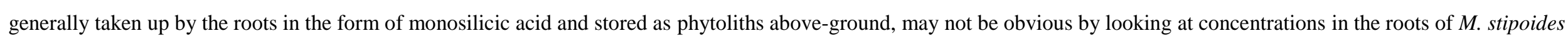
(Richmond and Sussman 2003). Other grass species have demonstrated high Si-accumulation capacities in the shoots (Cooke and Leishman 2011) and roots (Moore and Johnson

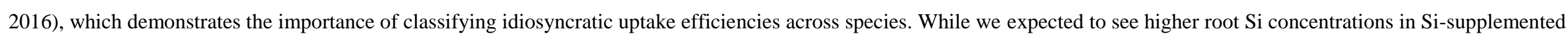

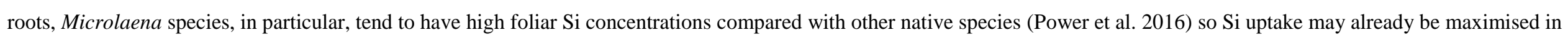

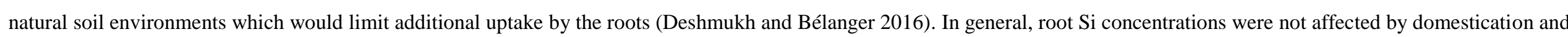

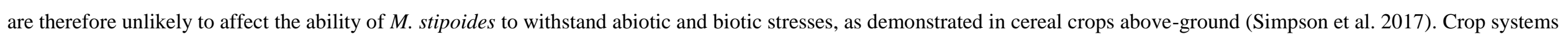

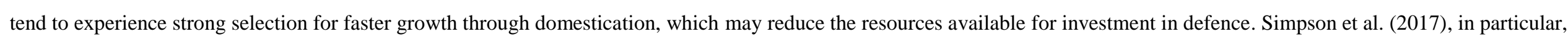

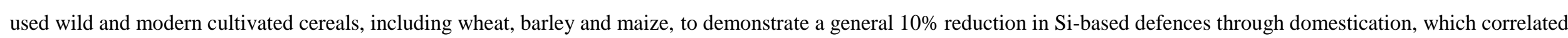
positively with leaf tensile strength (i.e. tearing force) and negatively with phenolic concentrations. However, the phenomenon of plants being 'disarmed by domestication' via a 
trade-off between defence investment and growth rate (Massei and Hartley 2000) has not been found by other studies (Turcotte et al. 2014; Whitehead et al. 2017). The use of

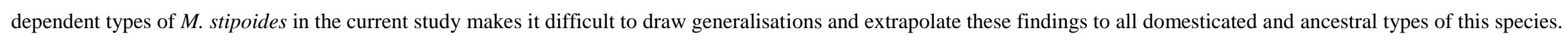
Future studies using multiple domesticated and ancestral types would provide further insight into how changes in root morphology can be used to improve plant performance.

Responses of Microlaena stipoides to water stress and its interaction with domestication

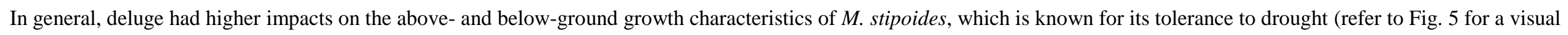
summary of the effects of deluge on M. stipoides). SRL decreased under the two extreme rainfall treatments, resulting from decreased investment in root length. Root depth

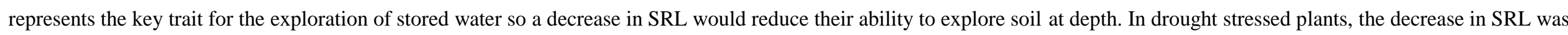

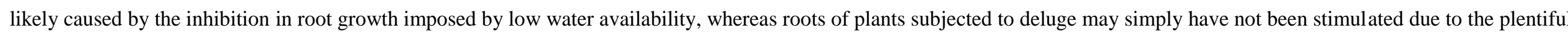

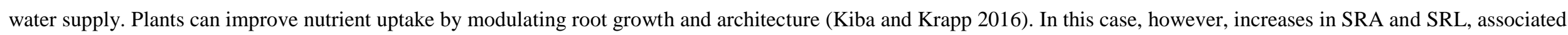

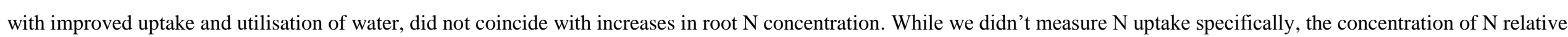

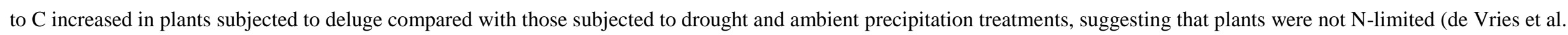

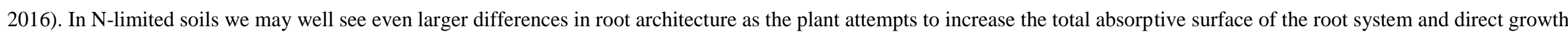
towards nutrient-rich soil patches (Kiba and Krapp 2016). Moreover, plants under deluge had relatively fewer fine roots compared with those under drought and ambient

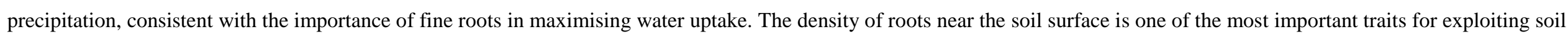

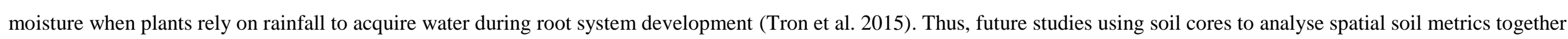
with architectural data may provide a useful indication of water and nutrient uptake efficiency. Measuring the abundance of fine roots at different depths within a soil core, for example, would enable us to determine how quickly the plants will take advantage of surface water and soil nutrient application.

The increase in plant and root growth under deluge observed in the current study, while increasing the ability to compensate for root damage, can have negative impacts on root

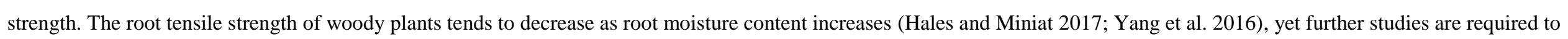

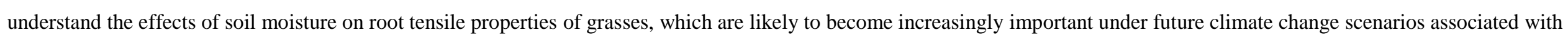

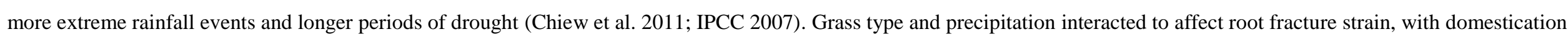
decreasing root fracture strain under drought conditions. If domesticated plants are weaker and less ductile under drought they may be more susceptible to root damage and

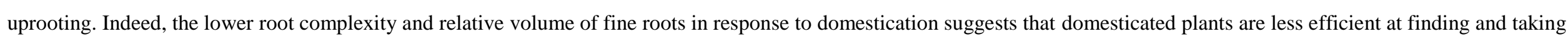
up water and/or nutrients from the soil (Mazzacavallo and Kulmatiski 2015). Domesticated plants may have been selected for optimal performance in irrigated systems, whereas

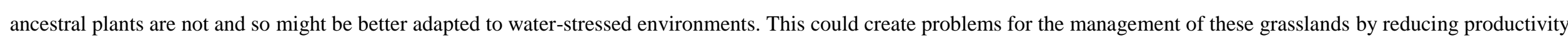


as the length of drought periods increase (Chiew et al. 2011; Fita et al. 2015). Precipitation did not interact with grass type to affect the tearing force required to break the roots, however, demonstrating the difficulty in finding a reliable metric for phenotyping root traits such as root physical strength.

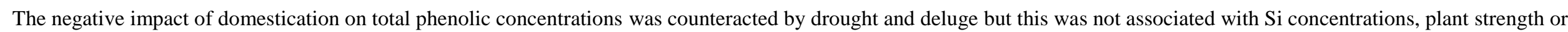

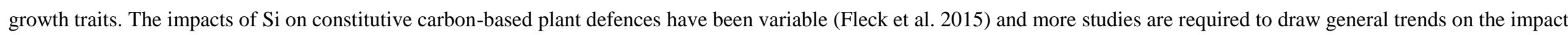
of Si on carbon-based plant defences, especially in the roots (Frew et al. 2016). While shoot herbivory is often the selective force for agricultural domestication, root defence compounds are important to consider as determinants of root strength and resistance to herbivores. Decreases in root phenolic concentrations, for example, have the potential to

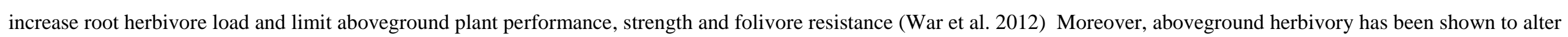
root phenolic concentrations, which may further interact with changes in water availability (Erb et al. 2015; Piwowarczyk et al. 2017). Water stress in general decreased phenolic concentrations in ancestral plants but had no effect on domesticated plants. Phenolic concentrations tend to be positively associated with resistance to herbivory so it could be envisaged that water-stressed ancestral plants were more susceptible to herbivory compared with domesticated plants that experience water stress. However, there are several examples of positive relationships between root herbivore performance and root phenolic concentrations that may be associated with alternative defence mechanisms (Frew et al. 2016; Johnson and Nielsen 2012). In general, plant defence theory (e.g. growth-differentiation balance hypothesis) predicts that increased plant productivity would result in

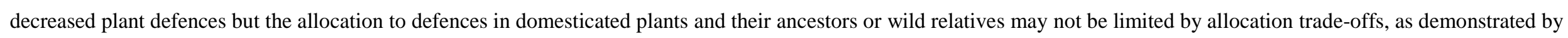
Turcotte et al. (2014).

\section{Conclusions}

Results show that breeding domesticated M. stipoides over a 10 year period has increased its RTD, rate of growth and tillering ability but decreased its SRL, SRA and fine root

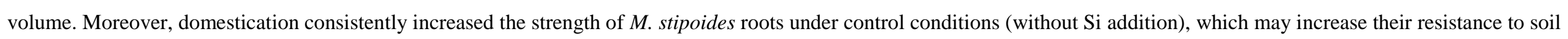
compaction (Striker et al. 2006), herbivory or other below-ground stress factors (Moore and Johnson 2016). However, decreases in below-ground complexity may show opposite

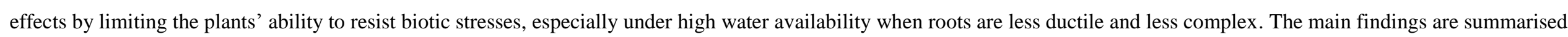

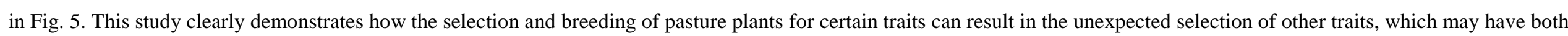
positive and negative consequences on herbivore population dynamics, especially for invertebrate communities that rely on the structural properties of the roots to survive.

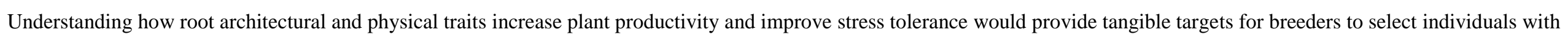
beneficial root phenotypes for enhanced plant performance.

\section{Accessibility}


Data deposited in the Dryad Digital Repository: doi: to follow

Supplementary material available in Online Resource 1:

Table S1 Chemical composition of Yarramundi loam soil used in experimental study.

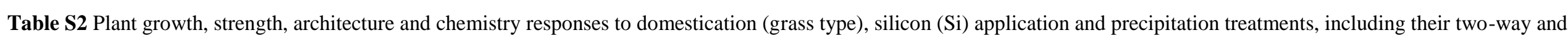
three-way interactions from general linear models and mixed-effect models.

Fig. S1 Device used to measure the tensile force required to tear the roots of Microlaena stipoides.

Fig. S3 The interactive effects of precipitation and domestication on total phenolic concentrations.

\section{Acknowledgements}

This research was funded by a Discovery Project grant from the Australian Research Council (ARC DP140100636) awarded to SNJ and BDM and an internship from the Hawkesbury Institute for the Environment awarded to MC. We would like to thank Dr. I. Chivers (Native Seeds Pty Ltd, Australia) for providing the seeds.

\section{References}

Børja I, De Wit HA, Steffenrem A, Majdi H (2008) Stand age and fine root biomass, distribution and morphology in a Norway spruce chronosequence in southeast Norway Tree Physiology 28:773-784 doi:10.1093/treephys/28.5.773

Bouma TJ, Nielsen KL, Koutstaal B (2000) Sample preparation and scanning protocol for computerised analysis of root length and diameter Plant Soil 218:185-196 doi:10.1023/a:1014905104017

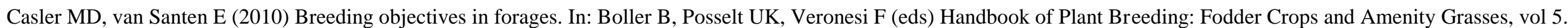
Springer, New York, USA, pp 129-150

Chen YH, Bernal CC (2011) Arthropod diversity and community composition on wild and cultivated rice Agricultural and Forest Entomology 13:181-189 doi:10.1111/j.14619563.2010.00510.x

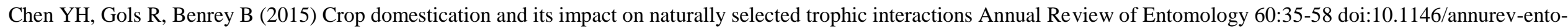
010814-020601 
Chen YH, Romena A (2008) Rice domestication decreases tolerance to the yellow stemborer, Scirpophaga incertulas International Rice Research Notes 32:21-27

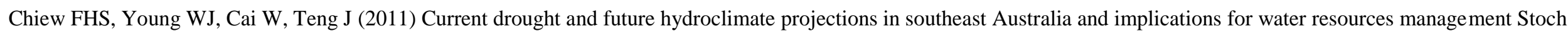
Environ Res Risk Assess 25:601-612 doi:10.1007/s00477-010-0424-X

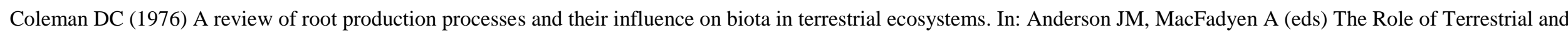
Aquatic Organisms in Decomposition Processes. Blackwell, Oxford, UK, pp 417-434

Comas LH, Becker SR, Cruz VM, Byrne PF, Dierig DA (2013) Root traits contributing to plant productivity under drought Frontiers in Plant Science 4:442 doi:10.3389/fpls.2013.00442

Cooke J, Leishman MR (2011) Is plant ecology more siliceous than we realise? Trends in plant science 16:61-68 doi:10.1016/j.tplants.2010.10.003

de Vries FT, Brown C, Stevens CJ (2016) Grassland species root response to drought: consequences for soil carbon and nitrogen availability Plant Soil 409:297-312 doi:10.1007/s11104-016-2964-4

Debona D, Rodrigues FA, Datnoff LE (2017) Silicon's role in abiotic and biotic plant stresses Annual Review of Phytopathology 55:4.1-4.23

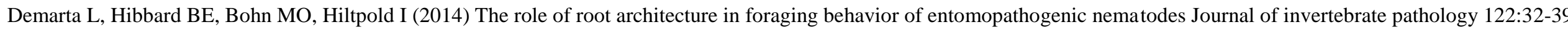
doi:10.1016/j.jip.2014.08.002

Deshmukh R, Bélanger RR (2016) Molecular evolution of aquaporins and silicon influx in plants Functional Ecology 30:1277-1285 doi:10.1111/1365-2435.12570

Ennos AR (1991) The mechanics of anchorage in wheat Triticum aestivum L.: I. THE ANCHORAGE OF WHEAT SEEDLINGS Journal of Experimental Botany 42:1601-1606 doi: $10.1093 / \mathrm{jxb} / 42.12 .1601$

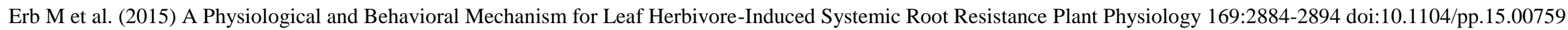

Evans LT (1996) Crop Evolution, Adaptation and Yield. Cambridge University Press, Cambridge, UK

Fita A, Rodríguez-Burruezo A, Boscaiu M, Prohens J, Vicente O (2015) Breeding and domesticating crops adapted to drought and salinity: a new paradigm for increasing food production Frontiers in Plant Science 6:978 doi:10.3389/fpls.2015.00978

Fleck AT, Schulze S, Hinrichs M, Specht A, Waßmann F, Schreiber L, Schenk MK (2015) Silicon promotes exodermal casparian band formation in Si-accumulating and Siexcluding species by forming phenol complexes PLOS ONE 10:e0138555 doi:10.1371/journal.pone.0138555

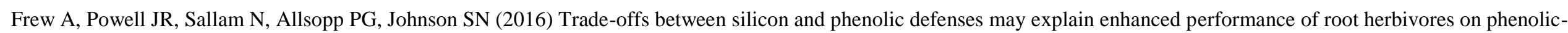
rich plants J Chem Ecol 42:768-771 doi:10.1007/s10886-016-0734-7

Glémin S, Bataillon T (2009) A comparative view of the evolution of grasses under domestication New Phytologist 183:273-290 doi:10.1111/j.1469-8137.2009.02884.X 
Gregory PJ (2006) Plant roots: growth, activity and interaction with soils. 1 edn. Blackwell, Oxford,

Hales TC, Miniat CF (2017) Soil moisture causes dynamic adjustments to root reinforcement that reduce slope stability Earth Surface Processes and Landforms 42:803-813 doi:10.1002/esp.4039

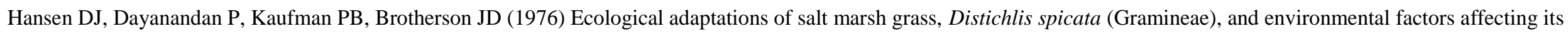
growth and distribution American Journal of Botany 63:635-650 doi:10.2307/2441826

Harlan JR, de Wet JMJ, Price EG (1973) Comparative evolution of cereals Evolution 27:311-325 doi:10.2307/2406971

Hartley SE, DeGabriel JL (2016) The ecology of herbivore-induced silicon defences in grasses Functional Ecology 30:1311-1322 doi:10.1111/1365-2435.12706

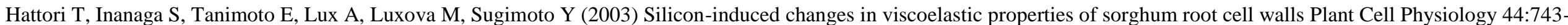
749

Hillman G, Hedges R, Moore A, Colledge S, Pettitt P (2001) New evidence of Lateglacial cereal cultivation at Abu Hureyra on the Euphrates The Holocene 11:383-393 doi:doi:10.1191/095968301678302823

Hiltpold I, Demarta L, Johnson SN, Moore BD, Power SA, Mitchell C Silicon and other essential element composition in roots using X-ray fluorescence spectroscopy: a high throughput approach. In: Johnson SN (ed) Invertebrate Ecology of Australasian Grasslands, Western Sydney University, Hawkesbury, NSW, Australia, 2016.

Hothorn T, Bretz F, Westfall P (2008) Simultaneous inference in general parametric models Biometrical Journal 50:346-363 doi:10.1002/bimj.200810425

Huyghe C, Brummer EC (2013) Forage and grasslands in a sustainable agriculture: new challenges for breeding. In: Sokolović D, Huyghe C, Radović J (eds) Quantitative Traits Breeding for Multifunctional Grasslands and Turf. Springer, Netherlands, pp 3-16. doi:10.1007/978-94-017-9044-4_1

IPCC (2007) Climate Change 2007: The Physical Science Basis, Contribution of Working Group I to the Fourth Assessment Report of the Intergovernmental Panel on Climate Change. Cambridge University Press, Cambridge, United Kingdom and New York, NY, USA,

Johnson SN, Hallett PD, Gillespie TL, Halpin C (2010) Below-ground herbivory and root toughness: a potential model system using lignin-modified tobacco Physiological Entomology 35:186-191 doi:10.1111/j.1365-3032.2010.00723.x

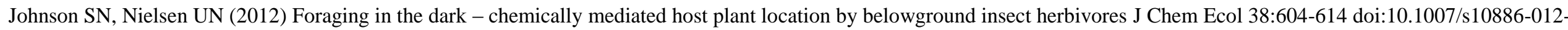
0106-X

Kiba T, Krapp A (2016) Plant nitrogen acquisition under low availability: Regulation of uptake and root architecture Plant Cell Physiology 57:707-714 doi:10.1093/pcp/pcw052

Lux A, Luxová M, Abe J, Tanimoto E, Hattori T, Inanaga S (2003) The dynamics of silicon deposition in the sorghum root endodermis New Phytologist 158:437-441 doi:10.1046/j.1469-8137.2003.00764.x 
Malory S (2014) Accelerated domestication of Australian native grass species using molecular tools. Southern Cross University

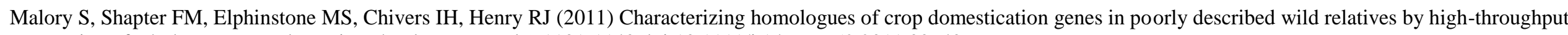
sequencing of whole genomes Plant Biotechnology Journal 9:1131-1140 doi:10.1111/j.1467-7652.2011.00640.x

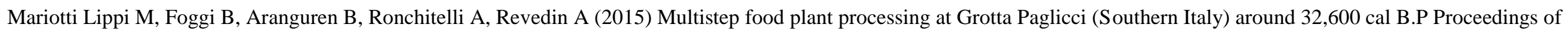
the National Academy of Sciences 112:12075-12080 doi:10.1073/pnas.1505213112

Marshall AH, Collins RP, Humphreys MW, Scullion J (2016) A new emphasis on root traits for perennial grass and legume varieties with environmental and ecological benefits Food and Energy Security 5:26-39 doi:10.1002/fes3.78

Massei G, Hartley SE (2000) Disarmed by domestication? Induced responses to browsing in wild and cultivated olive Oecologia 122:225-231

Mazzacavallo MG, Kulmatiski A (2015) Modelling water uptake provides a new perspective on grass and tree coexistence PLOS ONE 10:e0144300 doi:10.1371/journal.pone.0144300

Mitchell M (2013) Ecology of Microlaena stipoides in grazing systems. Charles Sturt University

Mitchell M, Stodart B, Virgona J (2014) Genetic diversity within a population of Microlaena stipoides, as revealed by AFLP markers Australian Journal of Botany 62:580-586

Moore BD, Johnson SN (2016) Get tough, get toxic or get a bodyguard: identifying candidate traits conferring belowground resistance to herbivores in grasses Frontiers in Plant Science 7:1925

Oksanen J et al. (2017) vegan: community ecology package. R package version 2.4-2.

Ostonen I et al. (2007) Specific root length as an indicator of environmental change Plant Biosystems 141:426-442 doi:10.1080/11263500701626069

Paez-Garcia A, Motes CM, Scheible W-R, Chen R, Blancaflor EB, Monteros MJ (2015) Root traits and phenotyping strategies for plant improvement Plants 4:334-355

Pérez-Harguindeguy N et al. (2013) New handbook for standardised measurement of plant functional traits worldwide Australian Journal of Botany 61:167-234 doi:10.1071/BT12225

Pinheiro J, Bates D, DebRoy S, Sarkar D (2017) nlme: linear and nonlinear mixed effects models. R package version 3.1-131 URL: http://cran.rproject.org/web/packages/nlme/index.html

Piwowarczyk B, Tokarz K, Makowski W, Łukasiewicz A (2017) Different acclimatization mechanisms of two grass pea cultivars to osmotic stress in in vitro culture Acta Physiologiae Plantarum 39:96 doi:10.1007/s11738-017-2389-6

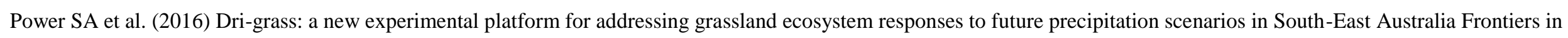
Plant Science 7 doi:10.3389/fpls.2016.01373 


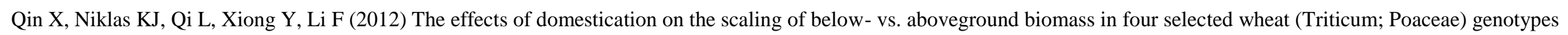
American Journal of Botany 99:1112-1117

R Core Team (2017) R: a language and environment for statistical computing. R Foundation for Statistical Computing, Vienna, Austria

Richmond KE, Sussman M (2003) Got silicon? The non-essential beneficial plant nutrient Current Opinion in Plant Biology 6:268-272 doi:http://dx.doi.org/10.1016/S1369$\underline{5266(03) 00041-4}$

Rosenthal JP, Welter SC (1995) Tolerance to herbivory by a stemboring caterpillar in architecturally distinct maizes and wild relatives Oecologia 102:146-155 doi:10.1007/BF00333245

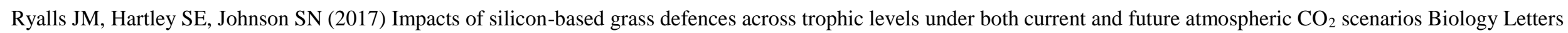
13:1-5 doi:10.1098/rsbl.2016.0912

Salminen J-P, Karonen M (2011) Chemical ecology of tannins and other phenolics: we need a change in approach Functional Ecology 25:325-338 doi:10.1111/j.13652435.2010.01826. $\mathrm{x}$

Shapter FM, Cross M, Ablett G, Malory S, Chivers IH, King GJ, Henry RJ (2013) High-throughput sequencing and mutagenesis to accelerate the domestication of Microlaena stipoides as a new food crop PloS one 8:e82641

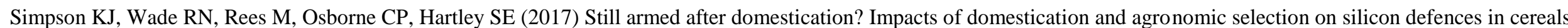
Functional Ecology Online early doi:10.1111/1365-2435.12935

Smartt J, Simmonds NW (1995) Evolution of Crop Plants. John Wiley \& Sons, New York

Sokolović D, Huyghe C, Radović J (2014) Quantitative Traits Breeding for Multifunctional Grasslands and Turf. Springer, Dordrecht

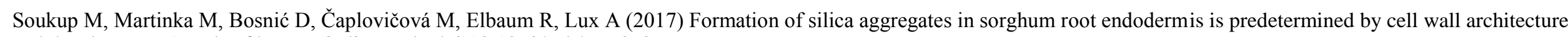
and development Annals of botany Online early doi:10.1093/aob/mcx060

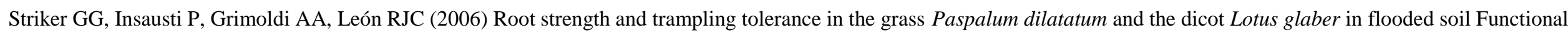
Ecology 20:4-10 doi:10.1111/j.1365-2435.2006.01075.x

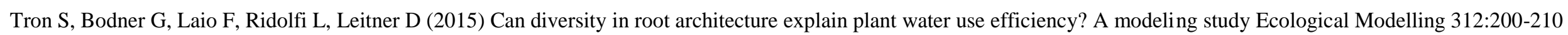
doi:https://doi.org/10.1016/j.ecolmodel.2015.05.028

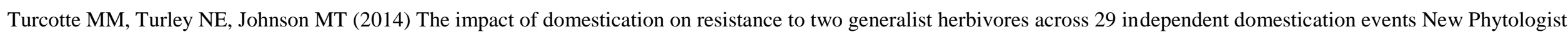
204:671-681 doi:10.1111/nph.12935 
War AR, Paulraj MG, Ahmad T, Buhroo AA, Hussain B, Ignacimuthu S, Sharma HC (2012) Mechanisms of plant defense against insect herbivores Plant Signaling \& Behavior 7:1306-1320 doi:10.4161/psb.21663

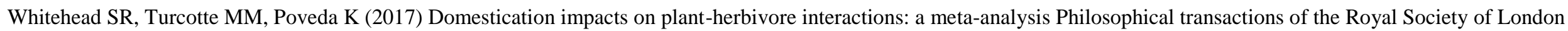
Series B, Biological sciences 372 doi:10.1098/rstb.2016.0034

Wickham H (2009) ggplot2: elegant graphics for data analysis. Springer-Verlag, New York

Yang Y, Chen L, Li N, Zhang Q (2016) Effect of root moisture content and diameter on root tensile properties PloS one 11:e0151791 
Table 1 Plant growth, root architecture and chemical responses to domestication (ancestral and domesticated Microlaena stipoides) and simulated precipitation treatments.

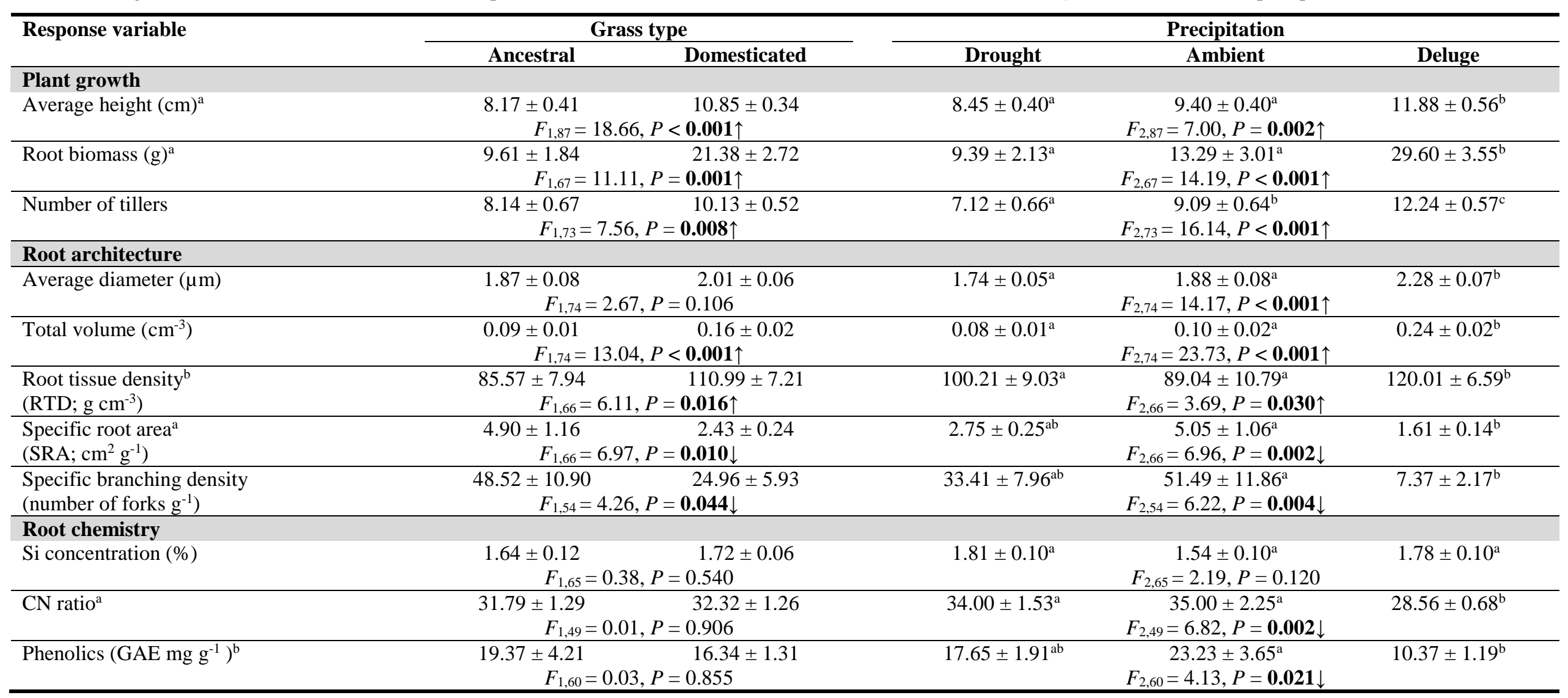

Overall means $( \pm \mathrm{SE})$ and statistics for treatment effects shown. $P$-values highlighted in bold indicate significance $(P<0.05)$. Where appropriate, response variables were transformed ( $\left.{ }^{a} \mathrm{Log},{ }^{\mathrm{b}} \mathrm{sqrt}\right)$ before analysis. Values with the same letters between precipitation treatments were not significantly different $(P<0.05)$ according to post hoc tests

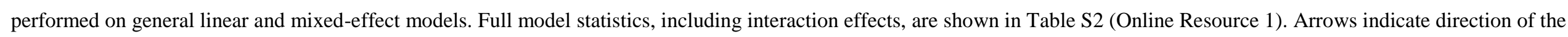
effect of domestication and deluge for grass type and precipitation treatments, respectively. Additional root architectural (specific root length and specific root tip density) and strength (fracture strain and tearing force) traits are displayed in Figs. 3 and 4, respectively. 


\section{Figure legends}

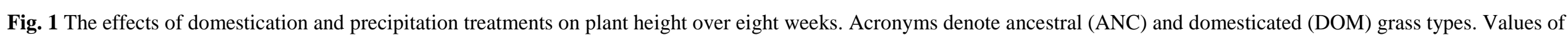
bars are means $( \pm \mathrm{SE})$.

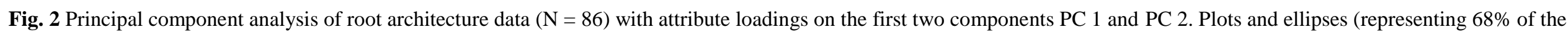

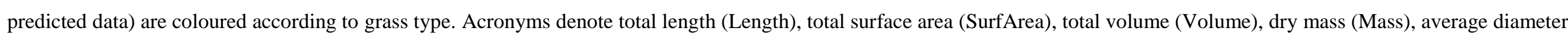
(Diameter), root tissue density (RTD), specific root length (SRL), specific root area (SRA), number of root tips $\mathrm{g}^{-1}$ dry mass (Tips) and number of forks $\mathrm{g}^{-1}$ dry mass (Branches)

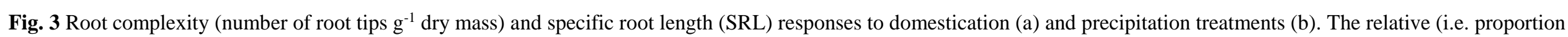
of total) volume $( \pm \mathrm{SE}$ ) of roots of different diameter classes in response to domestication and precipitation treatments are shown in $\mathrm{C}$ and $\mathrm{D}$, respectively

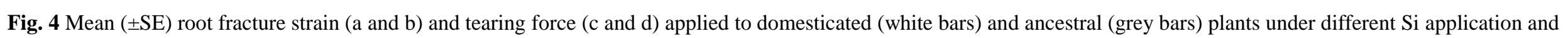
precipitation treatments. Bars with the same letters were not significantly different $(P<0.05)$

Fig. 5 Summary of key results illustrating the effects of domestication (right) and deluge (left) on the architectural and root toughness traits of Microlaena stipoides. Red arrows

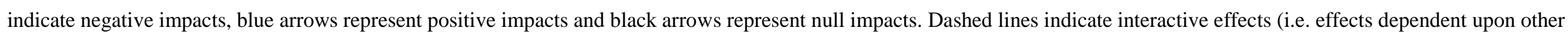

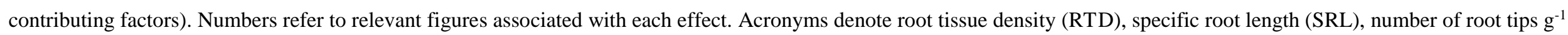
dry mass (Root tips) and number of forks $\mathrm{g}^{-1}$ dry mass (Branching) 
Fig. 1

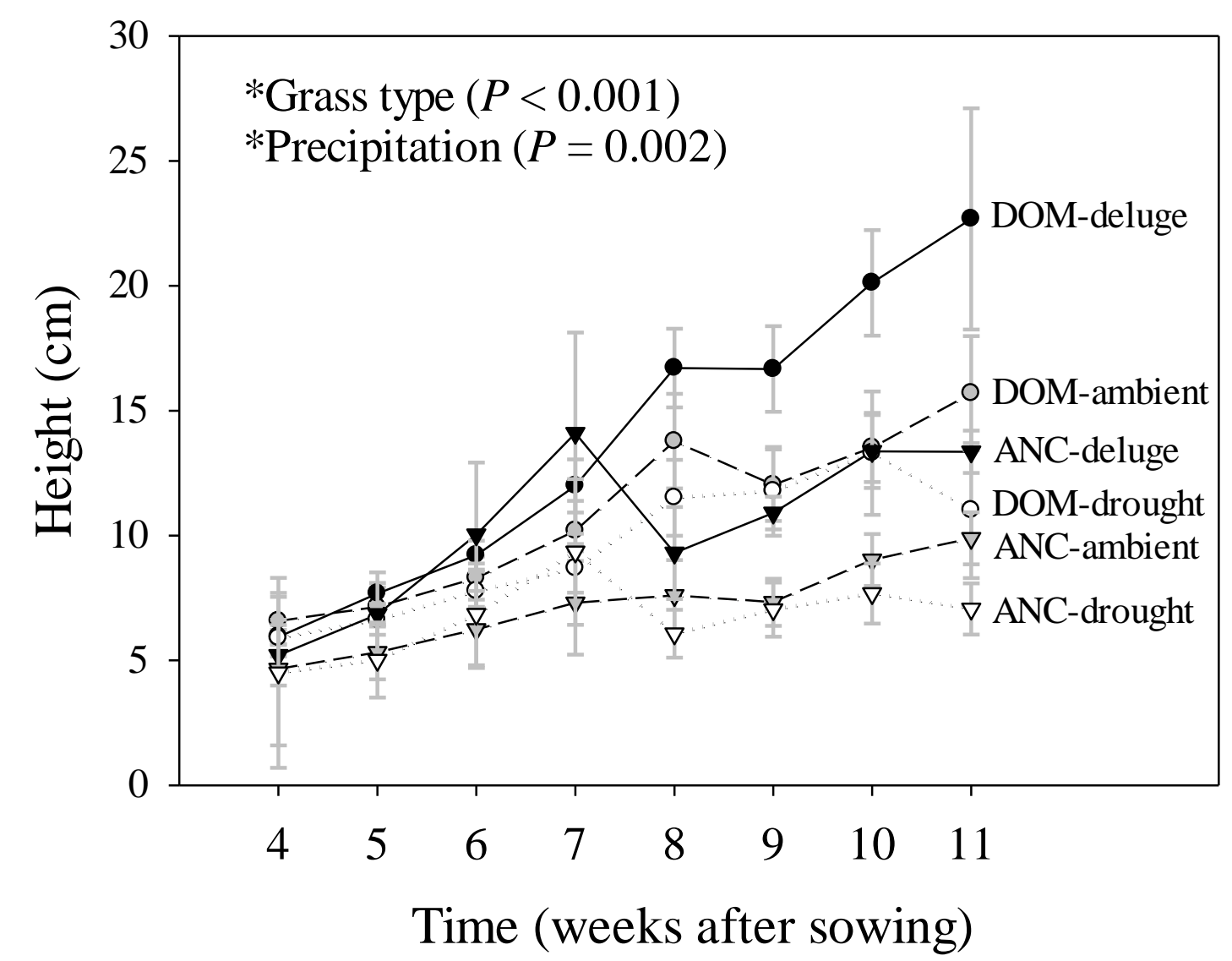


Fig. 2

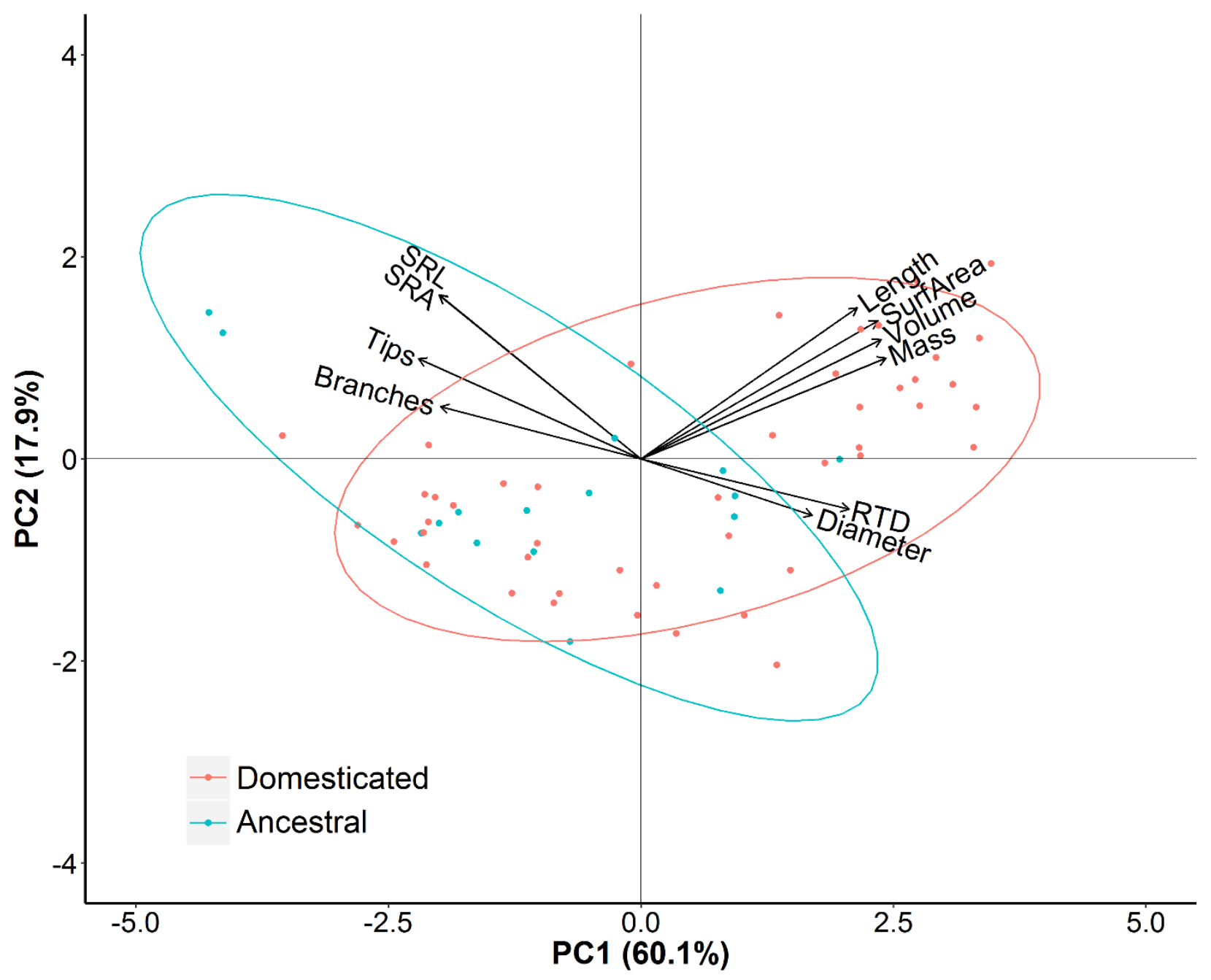


Fig. 3 

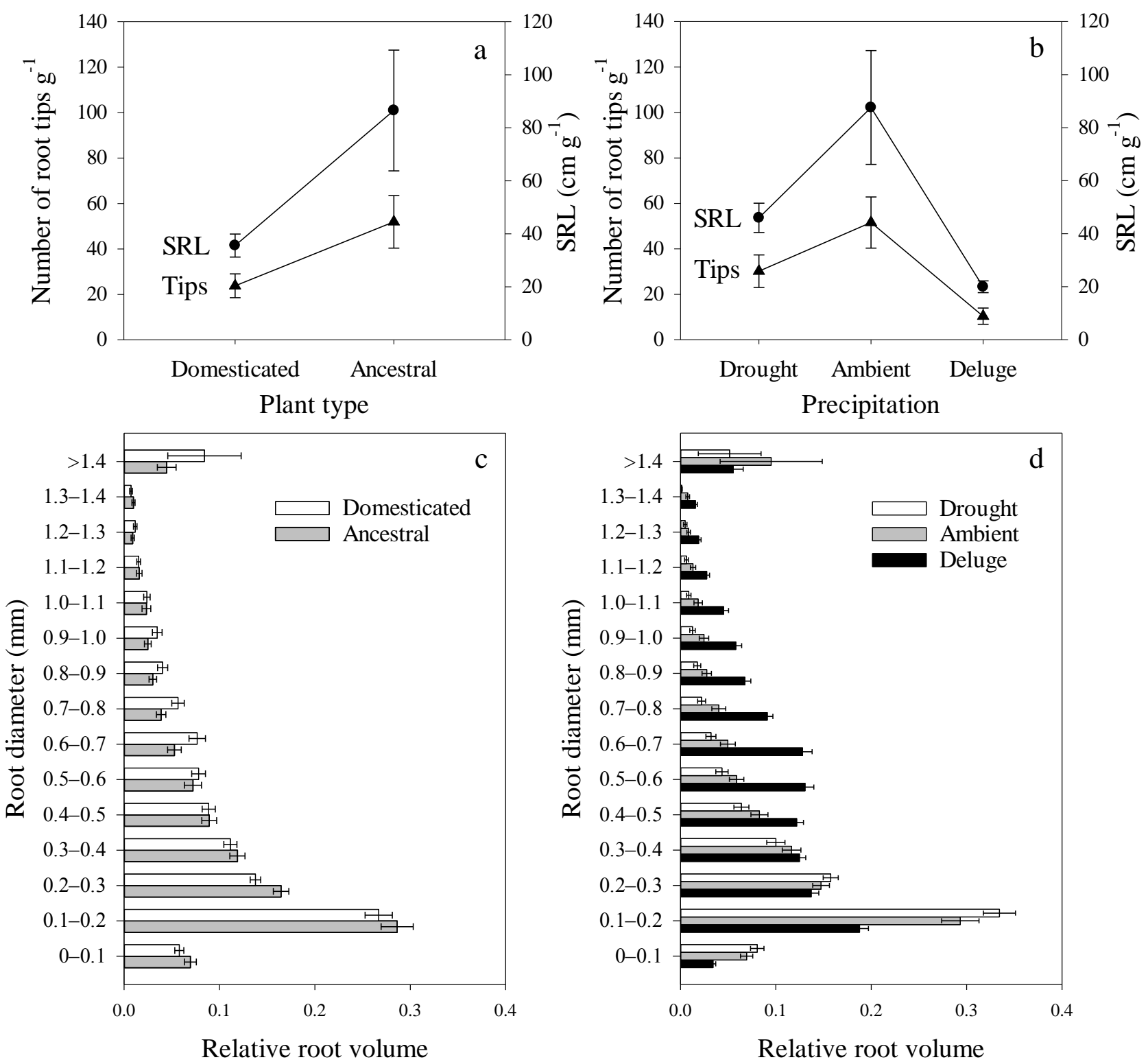
Fig. 4 

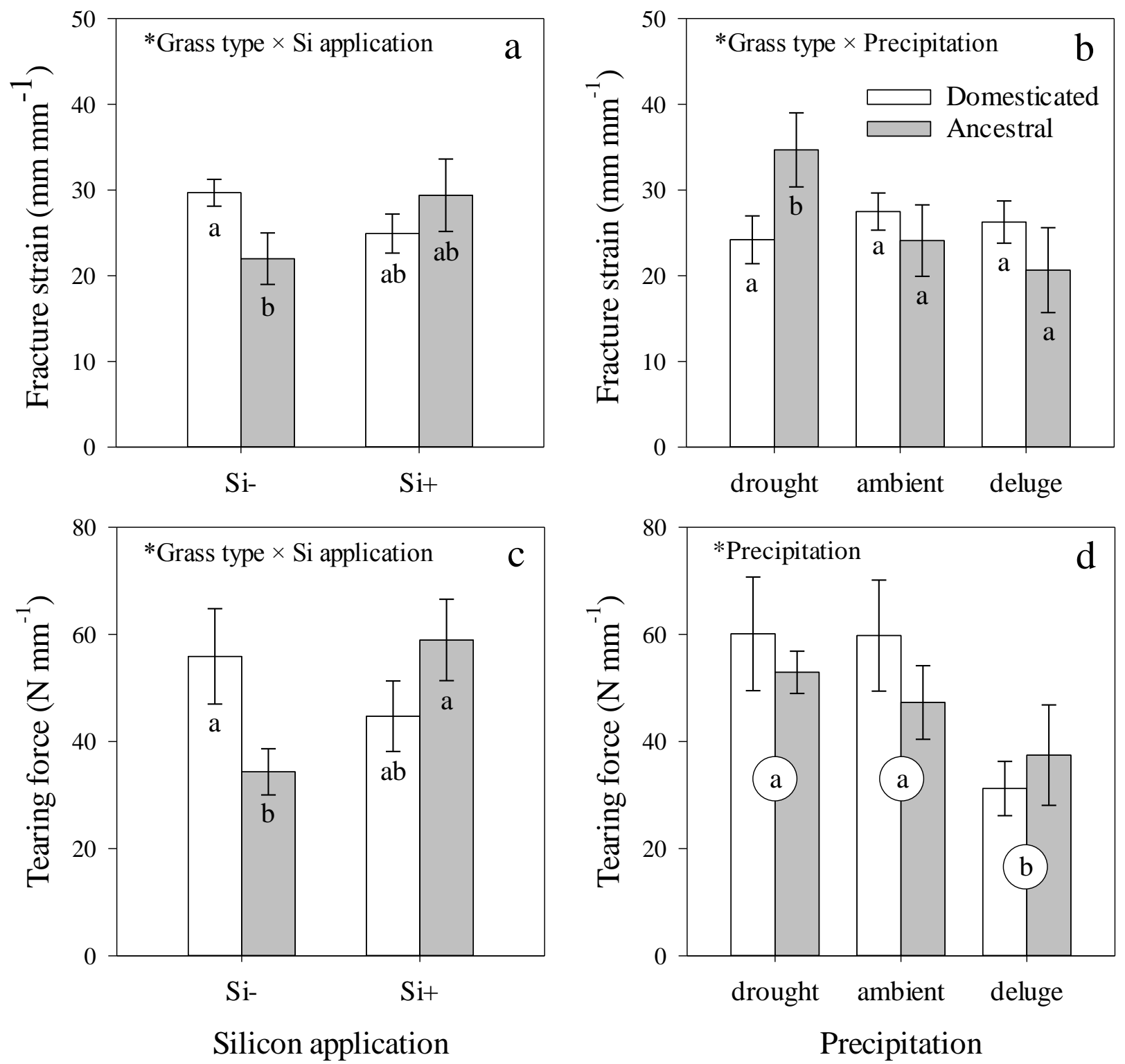
Fig. 5

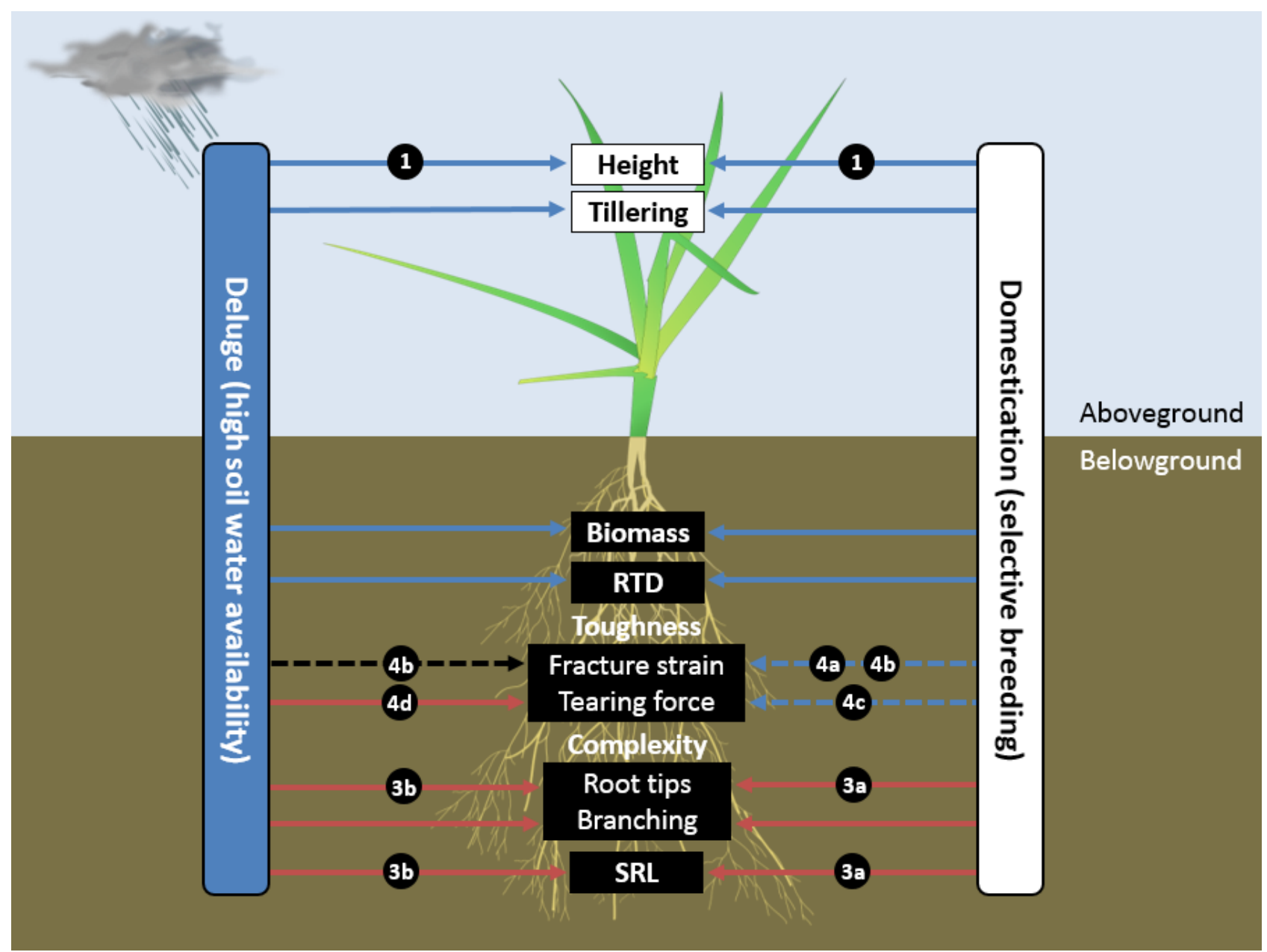


Online Resource 1 - Supplementary material

Root responses to domestication, precipitation and silicification: weeping meadow grass simplifies and alters toughness

James M.W. Ryalls ${ }^{1,2 *}$, Ben D. Moore ${ }^{1}$, Scott N. Johnson ${ }^{1}$, Myles Connor ${ }^{1}$ and Ivan Hiltpold ${ }^{1,3}$

${ }^{1}$ Hawkesbury Institute for the Environment, Western Sydney University, Richmond, NSW, Australia

${ }^{2}$ Current address: Centre for Agri-Environmental Research, School of Agriculture, Policy and Development,

University of Reading, $U K$

${ }^{3}$ Current address: Department of Entomology and Wildlife Ecology, University of Delaware, USA

*Corresponding author: $\quad \underline{\text { J.Ryalls@westernsydney.edu.au }}$

Tel: +61245701088 
Table S1 Chemical composition of Yarramundi loam soil used in experimental study.

\begin{tabular}{|c|c|c|c|c|}
\hline Method & Nutrient / Property & Units & Mean & Standard Error \\
\hline Colwell & Phosphorus & $\mathrm{mg} / \mathrm{kg}$ & 17.38 & 1.43 \\
\hline \multirow{3}{*}{$\mathrm{KCl}$} & Nitrate Nitrogen & \multirow{3}{*}{$\mathrm{mg} / \mathrm{kg}$} & 16.74 & 13.29 \\
\hline & Ammonium Nitrogen & & 2.75 & 0.37 \\
\hline & Sulfur & & 4.82 & 1.30 \\
\hline \multirow{2}{*}{ 1:5 Water } & $\mathrm{pH}$ & units & 6.12 & 0.24 \\
\hline & Conductivity & $\mathrm{dS} / \mathrm{m}$ & 0.05 & 0.02 \\
\hline Calculation & Estimated Organic Matter & $\% \mathrm{OM}$ & 2.66 & 0.71 \\
\hline \multirow{12}{*}{$\begin{array}{c}\text { Ammonium Acetate }+ \\
\text { Calculations }\end{array}$} & \multirow{3}{*}{ Calcium } & $\mathrm{cmol}^{+} / \mathrm{Kg}$ & 3.46 & 0.81 \\
\hline & & $\mathrm{kg} / \mathrm{ha}$ & 1552.04 & 364.26 \\
\hline & & $\mathrm{mg} / \mathrm{kg}$ & 692.87 & 162.62 \\
\hline & \multirow{3}{*}{ Magnesium } & $\mathrm{cmol}^{+} / \mathrm{Kg}$ & 0.78 & 0.10 \\
\hline & & $\mathrm{kg} / \mathrm{ha}$ & 213.13 & 26.62 \\
\hline & & $\mathrm{mg} / \mathrm{kg}$ & 95.15 & 11.88 \\
\hline & \multirow{3}{*}{ Potassium } & $\mathrm{cmol}^{+} / \mathrm{Kg}$ & 0.42 & 0.05 \\
\hline & & $\mathrm{kg} / \mathrm{ha}$ & 369.84 & 41.43 \\
\hline & & $\mathrm{mg} / \mathrm{kg}$ & 165.11 & 18.50 \\
\hline & \multirow{3}{*}{ Sodium } & $\mathrm{cmol}^{+} / \mathrm{Kg}$ & 0.09 & 0.02 \\
\hline & & $\mathrm{kg} / \mathrm{ha}$ & 44.91 & 8.53 \\
\hline & & $\mathrm{mg} / \mathrm{kg}$ & 20.05 & 3.81 \\
\hline \multirow{3}{*}{$\mathrm{KCl}$} & \multirow{3}{*}{ Aluminium } & $\mathrm{cmol}^{+} / \mathrm{Kg}$ & 0.02 & 0.00 \\
\hline & & $\mathrm{kg} / \mathrm{ha}$ & 3.66 & 0.62 \\
\hline & & $\mathrm{mg} / \mathrm{kg}$ & 1.63 & 0.28 \\
\hline \multirow{3}{*}{ Acidity Titration } & \multirow{3}{*}{ Hydrogen } & $\mathrm{cmol}^{+} / \mathrm{Kg}$ & 0.05 & 0.01 \\
\hline & & $\mathrm{kg} / \mathrm{ha}$ & 1.18 & 0.27 \\
\hline & & $\mathrm{mg} / \mathrm{kg}$ & 0.53 & 0.12 \\
\hline Calculation & Effective Cation Exchange Capacity (ECEC) & $\mathrm{cmol}^{+} / \mathrm{Kg}$ & 4.82 & 0.89 \\
\hline \multirow{2}{*}{ Base Saturation Calculations } & Calcium & \multirow{2}{*}{$\%$} & 70.46 & 3.55 \\
\hline & Magnesium & & 16.70 & 1.63 \\
\hline
\end{tabular}




\begin{tabular}{|c|c|c|c|c|}
\hline \multicolumn{3}{|c|}{ Potassium } & 9.30 & 1.65 \\
\hline \multicolumn{3}{|c|}{ Sodium - ESP } & 1.96 & 0.61 \\
\hline \multicolumn{3}{|c|}{ Aluminium } & 0.41 & 0.12 \\
\hline \multicolumn{3}{|c|}{ Hydrogen } & 1.17 & 0.34 \\
\hline Calculation & Calcium / Magnesium Ratio & ratio & 4.35 & 0.69 \\
\hline $\mathrm{CaCl}_{2}$ & Soil pH $\left(\mathrm{CaCl}_{2}\right)$ & units & 5.50 & 0.22 \\
\hline \multirow{4}{*}{ DTPA } & Zinc & \multirow{4}{*}{$\mathrm{mg} / \mathrm{kg}$} & 2.36 & 0.74 \\
\hline & Manganese & & 87.45 & 22.77 \\
\hline & Iron & & 70.46 & 5.00 \\
\hline & Copper & & 1.00 & 0.22 \\
\hline \multirow[t]{2}{*}{$\mathrm{CaCl}_{2}$} & Boron & \multirow[t]{2}{*}{$\mathrm{mg} / \mathrm{kg}$} & 0.29 & 0.03 \\
\hline & Silicon & & 23.42 & 0.83 \\
\hline \multirow{2}{*}{ LECO IR Analyser } & Total Carbon & $\%$ & 1.52 & 0.41 \\
\hline & Total Nitrogen & $\%$ & 0.12 & 0.03 \\
\hline Calculation & Carbon/ Nitrogen Ratio & ratio & 13.26 & 1.61 \\
\hline
\end{tabular}

Table S2 Plant growth, strength, architecture and chemistry responses to domestication (grass type), silicon (Si) application and precipitation treatments, including their two-way and three-way interactions from general linear models and mixed-effect models.

\begin{tabular}{|c|c|c|c|c|c|c|c|c|c|c|c|c|c|c|c|}
\hline \multirow[t]{2}{*}{ Response variable } & \multirow[t]{2}{*}{ df } & \multicolumn{2}{|c|}{ Grass type } & \multicolumn{2}{|c|}{ Precipitation } & \multicolumn{2}{|c|}{ Si application } & \multicolumn{2}{|c|}{$\begin{array}{l}\text { Grass type } \times \\
\text { Precipitation }\end{array}$} & \multicolumn{2}{|c|}{$\begin{array}{c}\text { Grass type } \times \\
\text { Si application }\end{array}$} & \multicolumn{2}{|c|}{$\begin{array}{c}\text { Precipitation } \times \\
\text { Si application }\end{array}$} & \multicolumn{2}{|c|}{$\begin{array}{c}\text { Grass type } \times \\
\text { Precipitation } \\
\times \\
\text { Si application } \\
\end{array}$} \\
\hline & & $F_{1}$ & $P$ & $F_{2}$ & $P$ & $\boldsymbol{F}_{1}$ & $P$ & $F_{2}$ & $P$ & $F_{1}$ & $P$ & $\boldsymbol{F}_{2}$ & $P$ & $F_{2}$ & $P$ \\
\hline \multicolumn{16}{|l|}{ Plant growth } \\
\hline Height* & 87 & 18.66 & $<0.001$ & 7.00 & 0.002 & 0.37 & 0.543 & 0.16 & 0.854 & 2.66 & 0.107 & 0.93 & 0.398 & 2.53 & 0.086 \\
\hline Root biomass* & 66 & 11.11 & 0.001 & 14.19 & $<0.001$ & 0.13 & 0.715 & 0.01 & 0.994 & 3.12 & 0.082 & 0.12 & 0.884 & 1.55 & 0.221 \\
\hline Number of tillers & 72 & 7.56 & 0.008 & 16.14 & $<0.001$ & 1.57 & 0.215 & 0.65 & 0.524 & 0.28 & 0.599 & 1.65 & 0.199 & 3.06 & 0.053 \\
\hline \multicolumn{16}{|l|}{ Root architecture } \\
\hline Total length* & 74 & 6.51 & 0.013 & 12.53 & $<0.001$ & 1.17 & 0.283 & 0.75 & 0.478 & 2.68 & 0.106 & 1.81 & 0.170 & 3.02 & 0.055 \\
\hline Total surface area* & 74 & 8.05 & 0.006 & 18.55 & $<0.001$ & 0.72 & 0.399 & 0.57 & 0.568 & 2.72 & 0.103 & 1.46 & 0.239 & 2.99 & 0.057 \\
\hline Average diameter & 74 & 2.67 & 0.106 & 14.17 & $<0.001$ & 0.13 & 0.719 & 0.10 & 0.910 & 0.14 & 0.714 & 0.15 & 0.862 & 0.90 & 0.413 \\
\hline
\end{tabular}




\begin{tabular}{|c|c|c|c|c|c|c|c|c|c|c|c|c|c|c|c|}
\hline Total volume & 74 & 13.04 & $<0.001$ & 23.73 & $<0.001$ & 0.01 & 0.910 & 1.63 & 0.203 & 1.04 & 0.310 & 1.41 & 0.252 & 2.27 & 0.111 \\
\hline Rel. fine root vol & 74 & 7.09 & 0.009 & 20.82 & $<0.001$ & 1.60 & 0.211 & 0.36 & 0.698 & 0.08 & 0.775 & 1.69 & 0.191 & 2.91 & 0.061 \\
\hline Root tissue density ${ }^{\#}$ & 66 & 6.11 & 0.016 & 3.69 & 0.030 & 0.79 & 0.376 & 0.91 & 0.406 & 3.78 & 0.056 & 0.61 & 0.547 & 0.96 & 0.389 \\
\hline Specific root length* & 66 & 7.24 & 0.009 & 7.99 & $<0.001$ & 1.22 & 0.274 & 1.32 & 0.274 & 3.53 & 0.065 & 0.17 & 0.842 & 0.72 & 0.489 \\
\hline Specific root area* & 66 & 6.97 & 0.010 & 6.96 & 0.002 & 1.60 & 0.210 & 1.29 & 0.282 & 3.61 & 0.062 & 0.34 & 0.711 & 0.69 & 0.504 \\
\hline Specific tip density & 54 & 6.99 & 0.011 & 6.02 & 0.004 & 1.23 & 0.272 & 0.17 & 0.842 & 2.66 & 0.108 & 0.01 & 0.994 & 0.08 & 0.922 \\
\hline Specific fork density & 54 & 4.26 & 0.044 & 6.22 & 0.004 & 0.62 & 0.434 & 0.14 & 0.872 & 1.56 & 0.216 & 0.01 & 0.995 & 0.49 & 0.617 \\
\hline \multicolumn{16}{|l|}{ Root strength } \\
\hline Fracture strain ${ }^{\#}$ & 71 & 0.11 & 0.737 & 0.47 & 0.626 & 0.16 & 0.687 & 3.88 & 0.025 & 5.30 & 0.024 & 1.87 & 0.162 & 2.28 & 0.110 \\
\hline Tearing force* & 72 & 0.18 & 0.666 & 3.60 & 0.032 & 0.07 & 0.789 & 0.94 & 0.395 & 4.63 & 0.035 & 1.12 & 0.331 & 0.02 & 0.982 \\
\hline \multicolumn{16}{|l|}{ Chemistry } \\
\hline Si concentration & 64 & 0.38 & 0.540 & 2.19 & 0.120 & 0.04 & 0.845 & 2.44 & 0.095 & 0.20 & 0.652 & 1.23 & 0.298 & 1.57 & 0.215 \\
\hline CN ratio* & 48 & 0.01 & 0.906 & 6.82 & 0.002 & 0.66 & 0.421 & 0.83 & 0.441 & 3.63 & 0.063 & 1.90 & 0.161 & 1.45 & 0.244 \\
\hline Phenolics $^{\#}$ & 59 & 0.03 & 0.855 & 4.13 & 0.021 & 3.71 & 0.059 & 8.20 & 0.001 & 0.01 & 0.936 & 2.91 & 0.062 & 0.94 & 0.396 \\
\hline
\end{tabular}

$P$-values highlighted in bold indicate significance $(P<0.05)$. Where appropriate, response variables were transformed $\left({ }^{*} \mathrm{Log}\right.$, ${ }^{*}$ sqrt $)$ before analysis. 


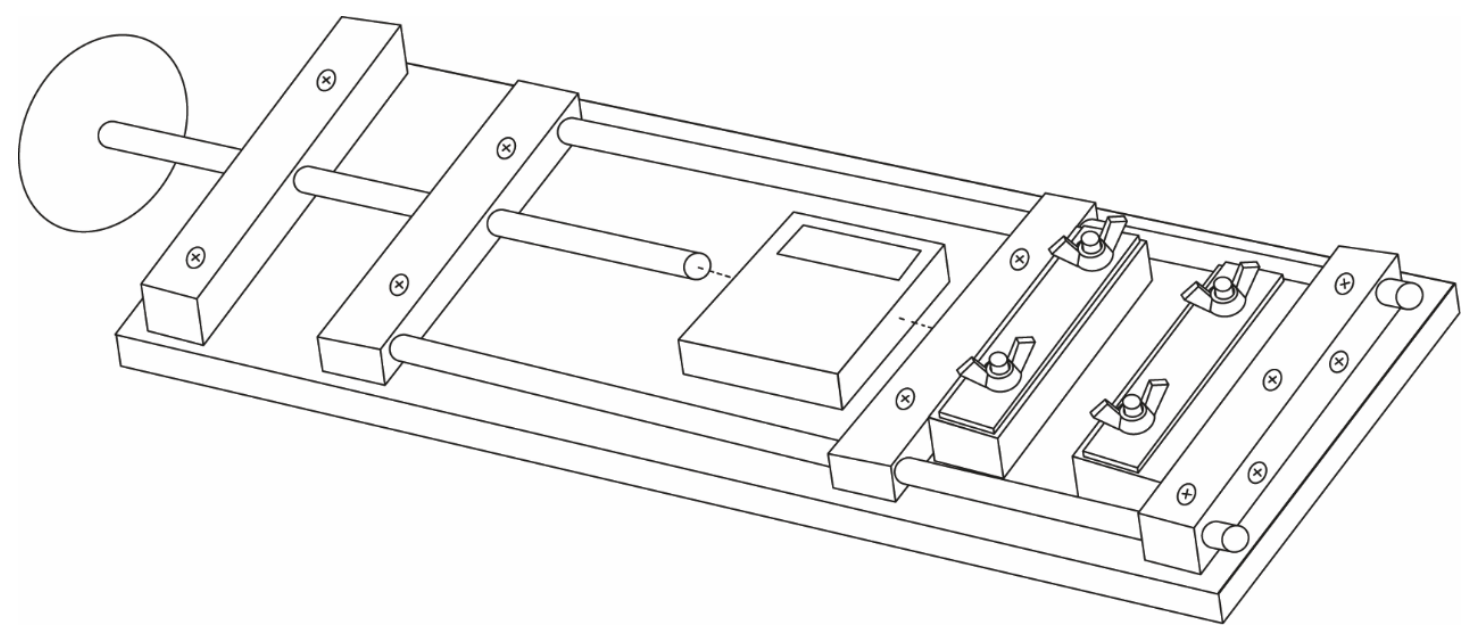

Fig. S1 Device used to measure the tensile force required to tear the roots of Microlaena stipoides. 


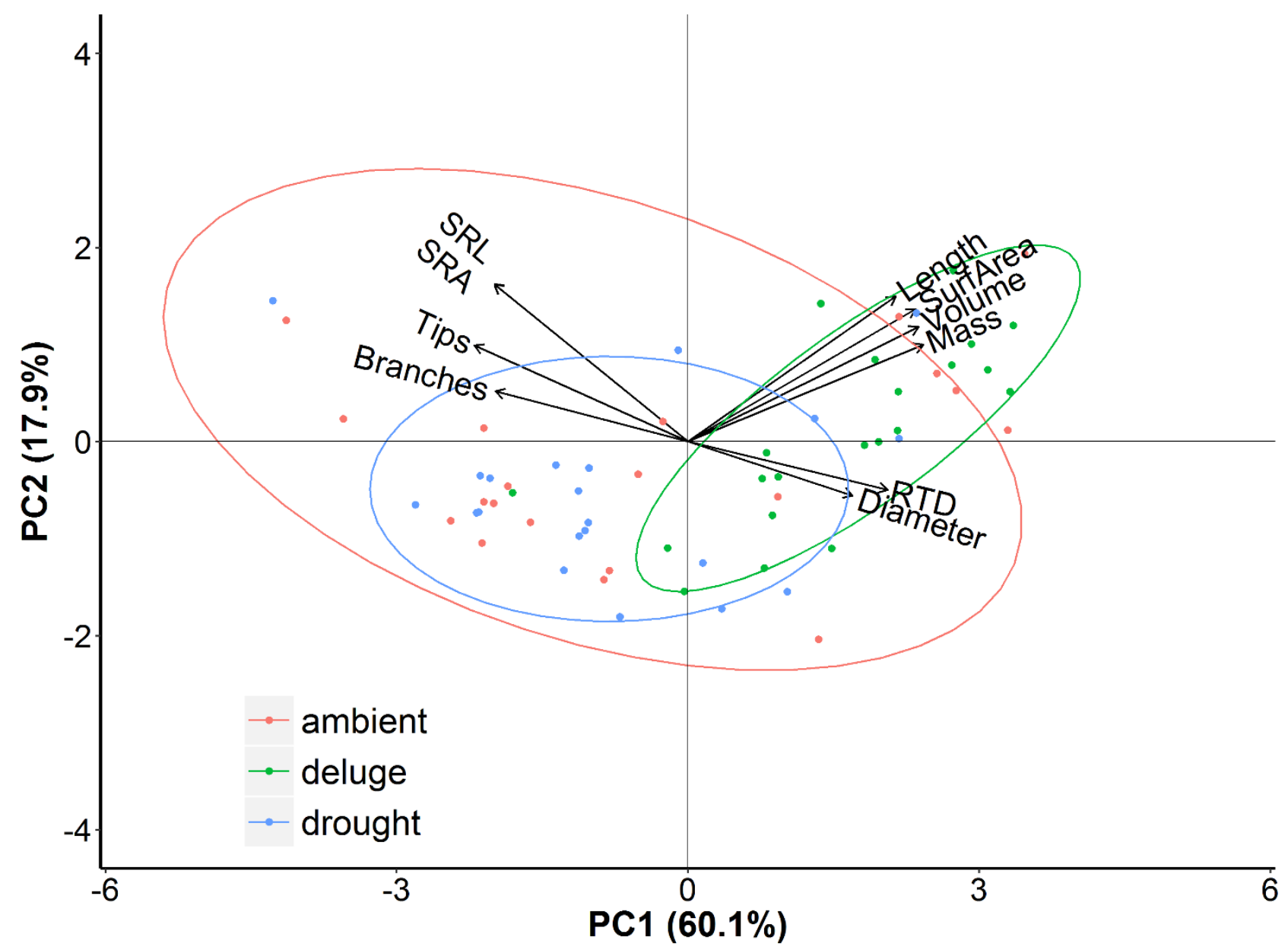

Fig. S2 Principal component analysis of root architecture data $(\mathrm{N}=86)$ with attribute loadings on the first two components PC 1 and PC 2. Plots and ellipses (representing 68\% of the predicted data) are coloured according to rainfall treatment. Acronyms denote total length (Length), total surface area (SurfArea), total volume (Volume), dry mass (Mass), average diameter (Diameter), root tissue density (RTD), specific root length (SRL), specific root area (SRA), number of root tips $\mathrm{g}^{-1}$ dry mass (Tips) and number of forks $\mathrm{g}^{-1}$ dry mass (Branches) 


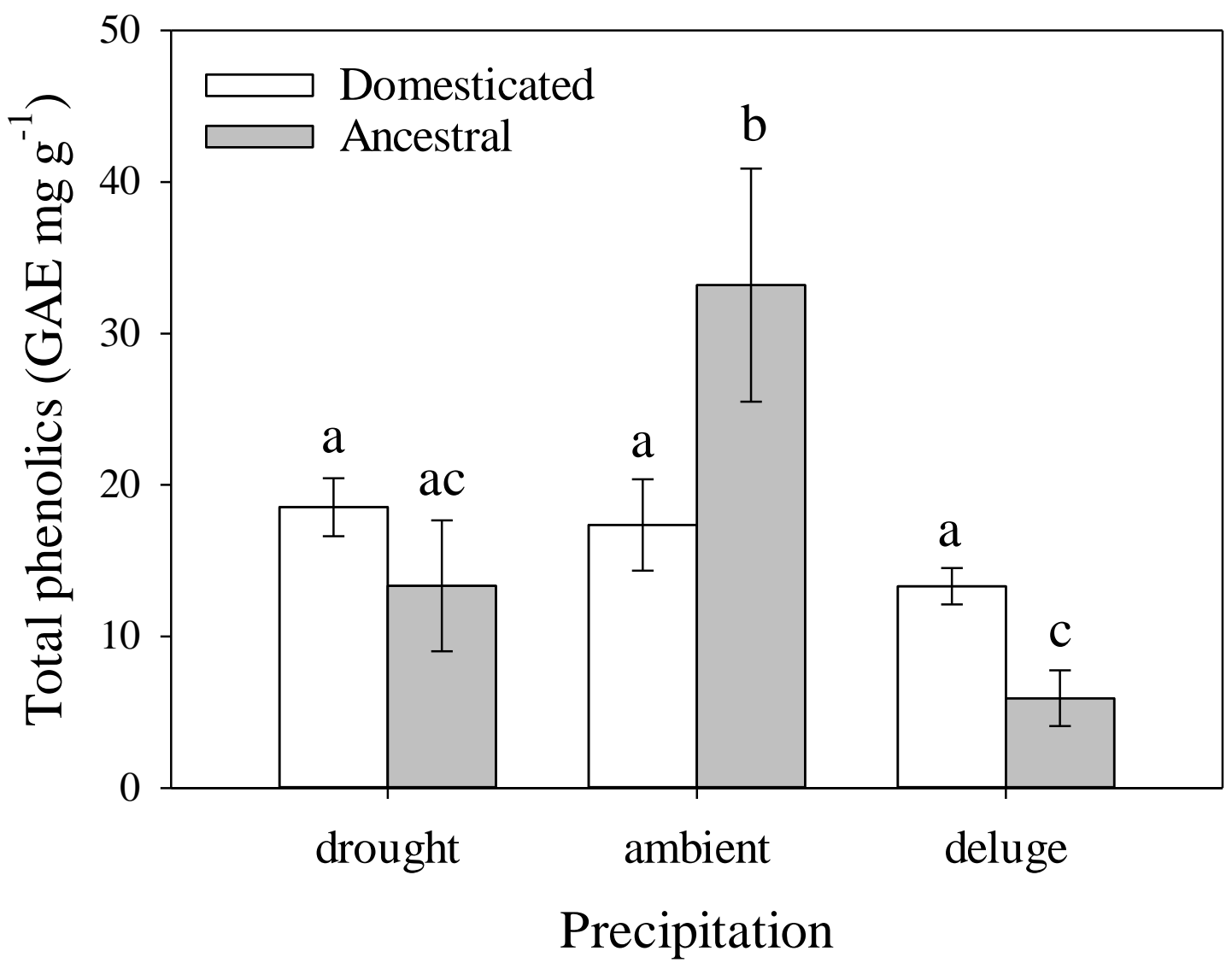

Fig. S3 The interactive effects of precipitation and domestication on total root phenolic concentrations. Mean values $( \pm$ SE) are shown. Bars with the same letters were not significantly different $(P<0.05)$. GAE refers to Gallic Acid Equivalent. 